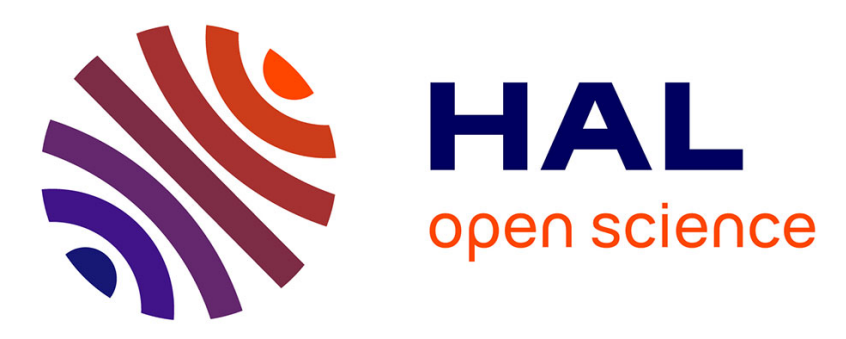

\title{
Flood events of selected european rivers in the sixteenth century
}

\author{
Rudolf Brázdil, Rüdiger Glaser, Christian Pfister, Petr Dobrovolný, \\ Jean-Marc Antoine, M. Barriendos, Dario Camuffo, Mathias Deutsch, Silvia \\ Enzi, Emanuela Guidoboni, et al.
}

\section{To cite this version:}

Rudolf Brázdil, Rüdiger Glaser, Christian Pfister, Petr Dobrovolný, Jean-Marc Antoine, et al.. Flood events of selected european rivers in the sixteenth century. Climatic Change, 1999, 43 (1), pp.239-285. hal-01511479

\section{HAL Id: hal-01511479 \\ https://hal-univ-tlse2.archives-ouvertes.fr/hal-01511479}

Submitted on 21 Apr 2017

HAL is a multi-disciplinary open access archive for the deposit and dissemination of scientific research documents, whether they are published or not. The documents may come from teaching and research institutions in France or abroad, or from public or private research centers.
L'archive ouverte pluridisciplinaire HAL, est destinée au dépôt et à la diffusion de documents scientifiques de niveau recherche, publiés ou non, émanant des établissements d'enseignement et de recherche français ou étrangers, des laboratoires publics ou privés. 


\title{
FLOOD EVENTS OF SELECTED EUROPEAN RIVERS IN THE SIXTEENTH CENTURY
}

\author{
RUDOLF BRÁZDIL ${ }^{1}$, RÜDIGER GLASER ${ }^{2}$, CHRISTIAN PFISTER ${ }^{3}$, PETR $^{2}$ \\ DOBROVOLNÝ ${ }^{1}$, JEAN-MARC ANTOINE ${ }^{4}$, MARIANO BARRIENDOS $^{5}$, \\ DARIO CAMUFFO ${ }^{6}$, MATHIAS DEUTSCH ${ }^{7}$, SILVIA ENZI ${ }^{8}$, EMANUELA \\ GUIDOBONI $^{9}$, OLDŘICH KOTYZA $^{10}$, FERNANDO SANCHEZ RODRIGO ${ }^{11}$ \\ ${ }^{I}$ Department of Geography, Masaryk University, Bmo, Czech Republic \\ ${ }^{2}$ Institute of Geography, University of Würzburg, Germany \\ ${ }^{3}$ Institute of History, University of Berm, Switzerland \\ ${ }^{4}$ Institute of Geography, University of Toulouse-Le Mirail, France \\ ${ }^{5}$ Department of Physical Geography, University of Barcelona, Spain \\ ${ }^{6}$ National Research Council, CNR-ICTMMA, Padua, Italy \\ ${ }^{7}$ Institute of Prehistoric Archaeology, Martin-Luther-University of Halle-Wittenberg, Germany \\ ${ }^{8}$ National Research Council, CNR-ISPAM, Venice, Italy \\ ${ }^{9}$ Storia Geofisica Ambiente, Bologna, Italy \\ ${ }^{10}$ Museum of Local History, Litomérice, Czech Republic \\ "Department of Applied Physics, University of Almeria, La Cañadá de San Urbano, Spain
}

\begin{abstract}
The severity and frequency of sixteenth-century floods of the Rhine, the Main, the middle and upper Elbe with its tributaries, rivers of northern and central Italy, the Garonne and rivers in Catalonia and Andalusia are analyzed using documentary evidence. The basic topographical and hydrological characteristics of the rivers investigated as well as the synoptic causes of their flooding during the instrumental period are presented. Different examples of modifications of the run-off process due to anthropogenic activity are discussed. Prevalence in flood occurrence during the second half of the sixteenth century in comparison to the first half is typical for central European and Andalusian rivers (mainly in the 1560s and 1590s) and agrees with the evolution of precipitation patterns. On the other hand, Italian and Catalonian rivers, in part, had a higher occurrence of floods during the first half of the century. Changes in the flooding seasons in both halves of the century are not unambiguous. Results of an analysis on a broader European scale show floods to be a random natural phenomena with limited areal extent defined by the spatial influence of forcing meteorological factors (continuous heavy rains, sudden melting of thick snow cover, etc.). Despite some limitations of documentary evidence, series of reconstructed historical floods are valuable sources of proxy data which can be utilized for the study of the flooding fluctuations in the pre-instrumental period.
\end{abstract}

\section{Introduction}

Floods are frequently referred to among extreme hydrometeorological phenomena in various historical sources. Their occurrence was often connected with damage to property and sometimes also with losses of human lives. For these reasons they did not remain unnoticed by annalists (Figure 1). However, episodes of high water which occurred in remote or uncultivated lands may remain unknown. Information about floods is usually included in documentary evidence (chronicles, diaries, economic records, etc.), epigraphic sources (data chiselled on so-called hunger 


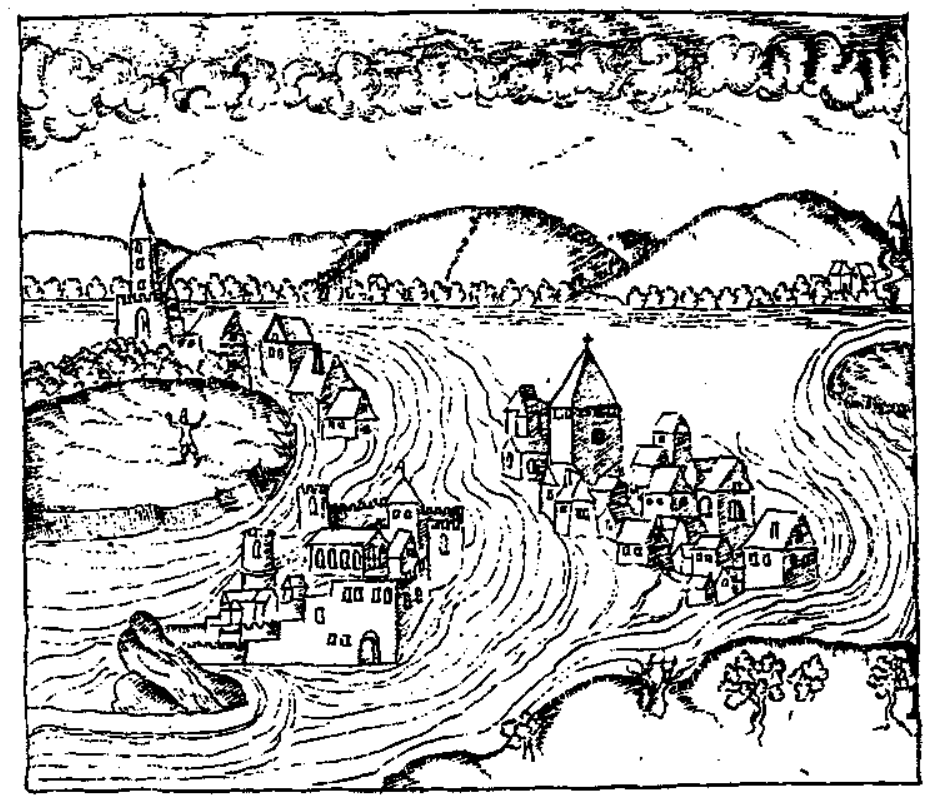

Figure 1. Floods and their damage were often the subjects of old pictures - the flood in Karlovy Vary (Bohemia) on 19 May 1582 caused by cloud-burst (Fritz, s.d.).

stones and rocks, flood-marks on buildings and flood monuments) and archaeological sources (e.g., extinction of settlements due to floods). Detailed characteristics of the consulted sources are described in the paper by Pfister et al. (this volume). Documentary evidence of floods differs in the various records, some appearing as a mere statement of the occurrence of a flood and others providing more detailed reports including comments regarding the cause of the flood, its course and, particularly, the description of the damage caused. This data often comprises information about the highest water level reached during the flood. This study is based on written sources, supplemented by contemporary illustrations and flood marks on historical buildings (Figure 2) and/or on rocks or stones. This evidence needs to be critically analyzed. Only verified, original text sources, preferably written by authors who had lived at the time of a given event, were used in this study. Special consideration was given to floods referred to independently by more than one observer.

Sets of data about historical floods obtained in this way can be analyzed with respect to the frequency of occurrence, the cause and/or the estimate of the damage. These data, of course, do not include quantitative hydrological information about the flood proper, i.e., about cumulated water volume or the duration of the event. Although occasional reports give an idea about the size of a flood, they are practically inapplicable in the estimation of discharge rates owing to the fact that the changes in a particular discharge section at any given time are not known. Besides the quality of the reports themselves, the main problem is their 


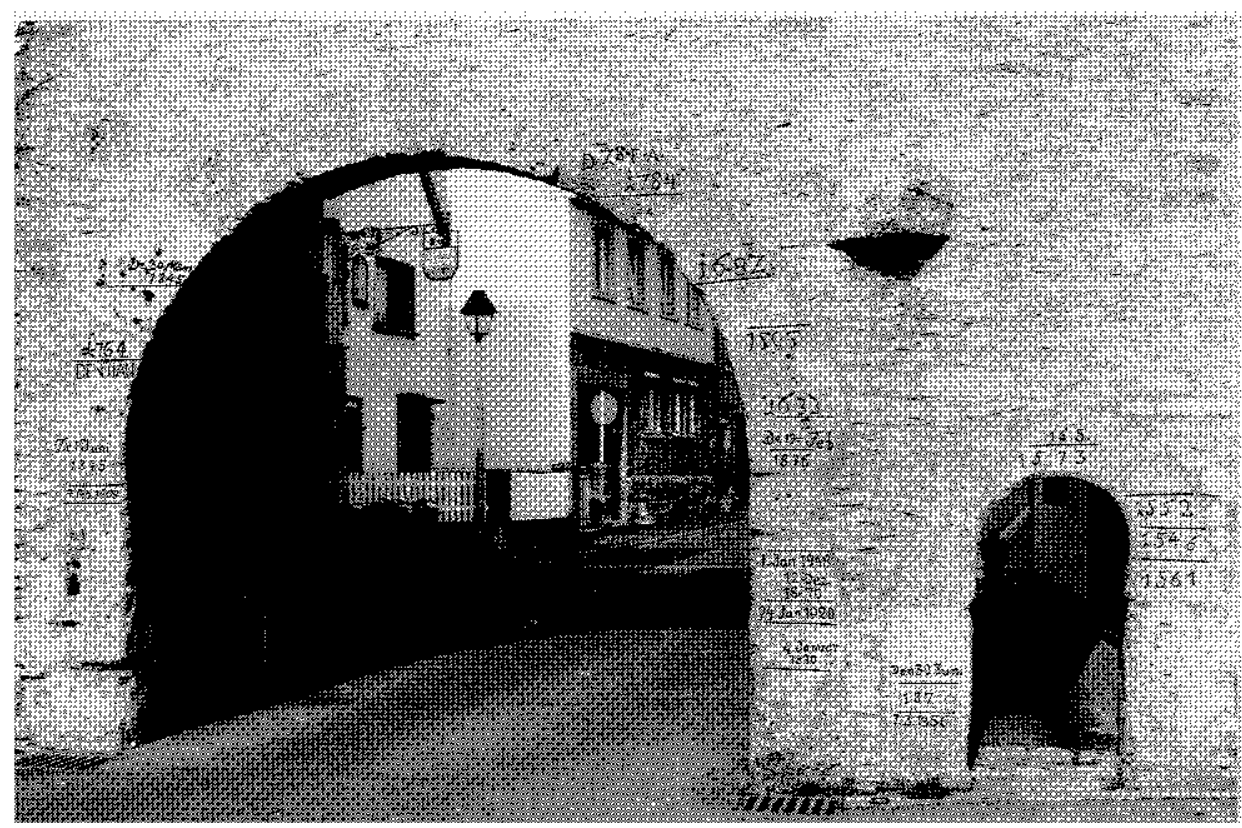

Figure 2. Marks of water levels on the Main Gate in Eibelstadt, Germany (Photo: R. Glaser).

unsystematic character. The variable density of records concerning a specific flood can, for instance in the case of only a small number of recorded observations, significantly influence the statistical conclusions obtained.

Several European compendia exist containing accounts about floods in the sixteenth century (e.g., Pötzsch, 1784; Weikinn, 1960). Although they also include information about the source from which a given report comes, it is especially necessary to critically evaluate the accounts included therein. Reports copied from less than credible sources are frequently found in such reference work and errors in dating are particularly prevalent. When one and the same flood is erroneously ascribed to different dates or years, the result is an overestimation of the frequencies of occurrence of the phenomenon (e.g., Bell and Ogilvie, 1978). Additionally, in the late sixteenth century matters became even more complicated through the calendar reform introduced by Pope Gregory XIII. The old Julian calendar was officially replaced by the new Gregorian calendar in October 1582. At that time the difference in dating between the two calendars amounted to 10 days. The reform was accepted immediately or with only little delay by the Catholic church (e.g., 1584 in the Czech Lands), but it was substantially later before Protestant states gradually acknowledged it. In the present paper all dates appear in the converted New Style of the Gregorian system (for more details see Pfister et al., this volume).

Recent studies of different aspects of historical floods in Europe, mainly on a local or a regional scale, include those by Pfister (1988), Glaser and Hagedorn 
(1990), Pfister and Hächler (1991), Röthlisberger (1991), Witte (1991), Pavese et al. (1992), Camuffo and Enzi (1995), Kotyza et al. (1995), Deutsch and Pörtge (1996), Pfister (1996), Gees (1997), Krahe (1997) and Barriendos and MartínVide (1998). However, only some of them devote special attention to flood activity during the sixteenth century. The present paper analyzes flood events of selected central and southern European rivers during the sixteenth century. The first region represents a typical climate of the mid-latitudes and the latter stands for the western and central Mediterranean climate.

Each flood event is a result of a complex web of meteorological (mainly precipitation), environmental (e.g., physical characteristics of surface or vegetation cover) or anthropogenic (e.g., breaking embankments in war action) factors on the river run-off (Mendel et al., 1997). The temporal and spatial variability in operation of the above factors conditions the occurrence and the severity of individual floods. Changes of meteorological factors are connected with climatic fluctuations whereas changes of environmental factors depend mainly on anthropogenic activity (deforestation, regulation of streams, water structures, etc.). In interpreting flood events it is important to discern between the disposition of the long-term weather patterns several weeks or months prior to the event, and the short period of intensive rainfall that triggers the flood peak (BA Wasserwirtschaft, 1991).

From a meteorological point of view it is necessary for central Europe to distinguish between floods caused by (i) short but intense precipitation (downpours, cloud-bursts), (ii) long-lasting continuous rainfalls and (iii) the melting of snow cover (Brádka, 1967). Generally, the first type of flood occurs on a local scale and often has disastrous local impacts. The other two types of floods are essentially connected with larger territorial regions. In the case of continuous precipitation, the amount and duration of the water saturation in the catchment area is decisive. Floods due to melting snow depend mainly on the height and the water equivalent of the snow cover, freezing soil, intensity of warming and the situation of ice on rivers, due to the effects of thawing possibly being combined with the rainfall. Another type of reported flood is connected with ice drift or an accumulation of floating ice along some river courses. In mountainous regions rapidly melting snow may occur with the onset of warm winds such as the "sirocco" or "foehn". Sometimes only a little warming is sufficient to displace large snow masses (i.e., avalanches) to a lower elevation where the higher temperature will melt the accumulated snow. In the Mediterranean climate, variations of floods are caused by episodes of very intense precipitation. The catchment areas affected do not have sufficient capacity to store the amount of precipitation and flooding then occurs.

With regards to the facts mentioned above, great temporal and spatial variability in the occurrence and severity of floods can be expected. Their study is also very important with respect to the large flood events of the last two decades of 

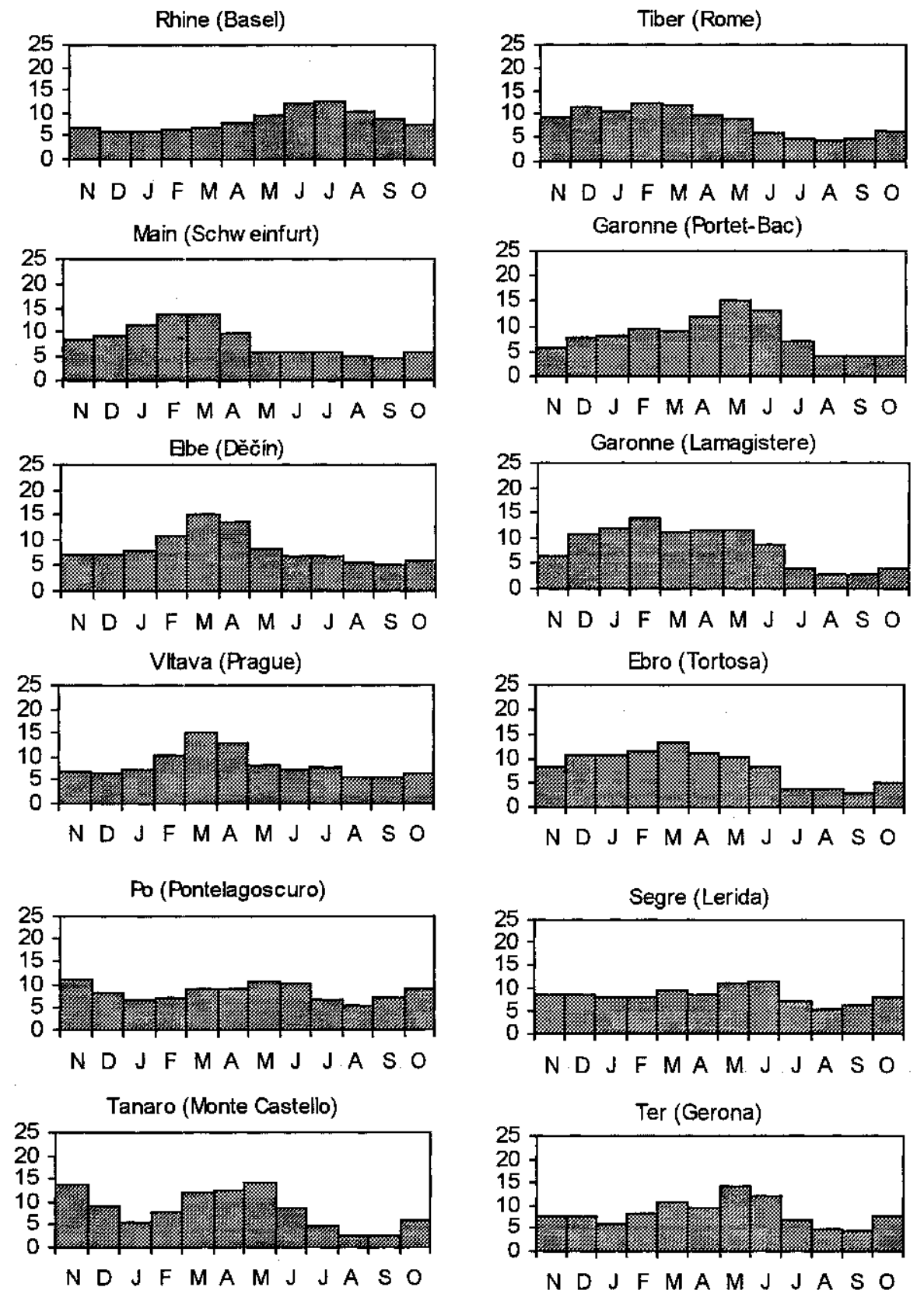

Figure 3. Annual distribution of discharge rates (\%) for selected rivers of central and southern Europe (see Table I for periods).

this century, for example, the devastating flood in August 1987 in Switzerland in the region of the St. Gotthard (Pfister and Hächler, 1991), the catastrophic floods 

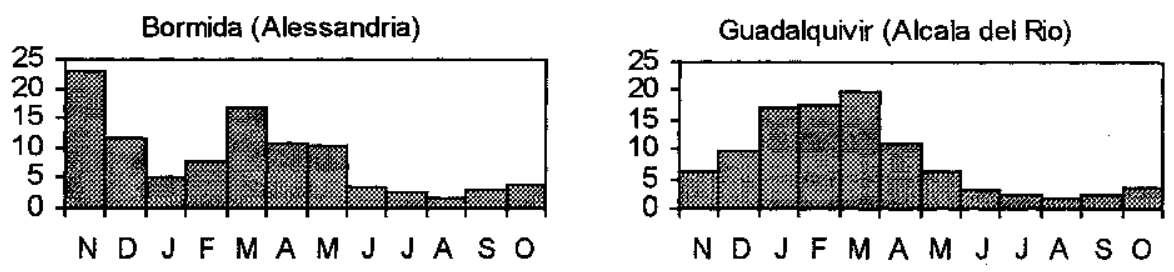

NDJFMAM J J A S O
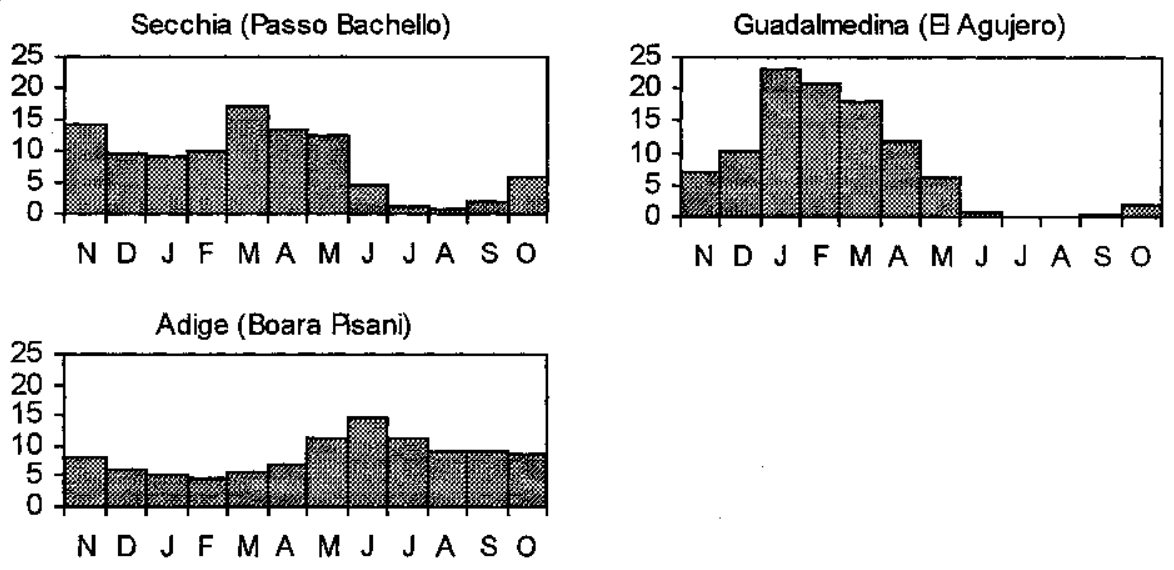

Figure 3. (Continued)

of the Rhine and the Meuse in December 1993 and January 1995 (Engel, 1995; Fink et al., 1996), the devastating flood of April 1994 in Thuringia and SaxonyAnhalt (Spanknebel et al., 1994) and the immense flood catastrophe of July 1997 in the Czech Republic, Poland and Germany (e.g., Kakos, 1997; Soukalová et al., 1997). This study may eventually lead to a better understanding of repetitive hydrological patterns.

In recent years floods have been a topic of interest in conjunction with global warming and expected climatic change. Although the Second Assesment Report of the Intergovernmental Panel on Climate Change (IPCC) notes that "there have been few studies of variations in extreme rainfall and flood frequency" (Houghton et al., 1996) on the regional level, great attention is devoted to the estimation of possible changes in the run-off process when considering expected climatic change (e.g., Přenosilová, 1994; Kabubi et al., 1995; Gellens and Schädler, 1996, 1997; Hladný et al., 1996; Casale et al., 1997, 1998; Grabs, 1997). However, as Kuusisto et al. (1994) mentioned, all the current studies concerning hydrological extremes in the future are highly speculative. This is because of the uncertainty of GCM predictions of precipitation as well as the use of hydrological models, even the most physically-based ones which may not fully or adequately represent the reaction of the catchment areas. Knowledge of historical floods and their causes might be useful for the study of this problem on a long-term scale. 


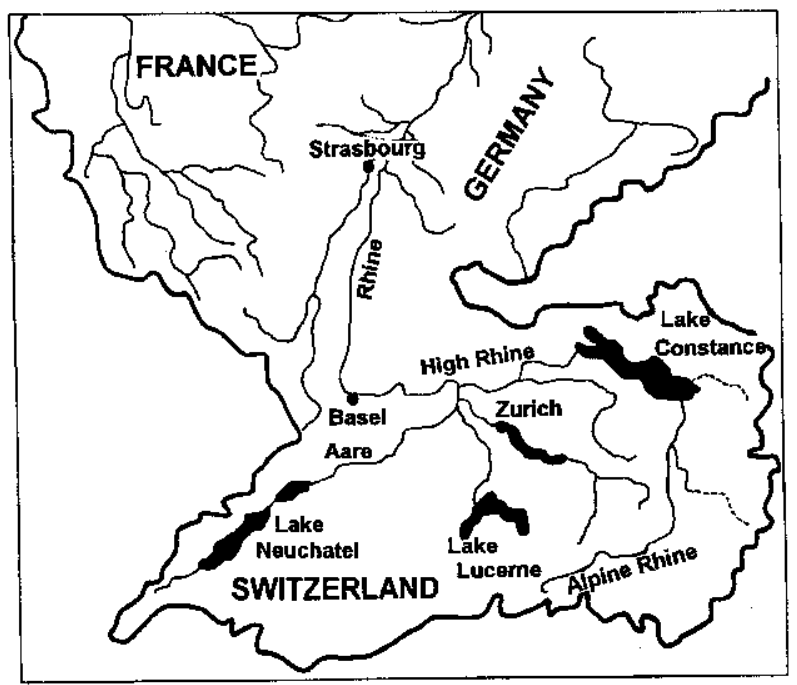

Figure 4. Part of the catchment area of the Rhine.

\section{Topographical and hydrological characteristics of rivers investigated}

Basic information about geographical and hydrological characteristics of the rivers investigated is presented in Table I. It was impossible to obtain data concerning discharge rates for selected water gauge stations on the individual rivers during the same reference period. However, depending on the selection of the period, it can be assumed that the basic character of the annual discharge rates distribution does not change conspicuously. According to the monthly distribution of annual discharge rates for the main rivers analyzed (Figure 3), it is possible to distinguish among the following groups of rivers:

a) The Rhine

The Rhine is the largest river in central and western Europe. Concerning it's hydrological properties and landforms, the Rhine's basin is geographically subdivided into five parts from source to mouth (Figure 4): 1. the Alpine Rhine (Alpenrhein) to Lake Constance, 2. the High Rhine (Hochrhein) to Basel, 3. the Upper Rhine between Basel and Mainz, 4. the Middle Rhine from Mainz to Düsseldorf and 5. the Lower Rhine from Düsseldorf to the mouth. The area upstream from Basel covers only $20 \%$ of the basin, but it accounts for almost $50 \%$ of the total discharge rate of the river. A pronounced maximum discharge occurs in the summer months, the minimum is reached during the winter months. The maximum discharge is the result of the melting snow (accumulated from October to May) during early summer in combination with a summer precipitation maximum caused by convection due to the blocking of north-westerly airflows (Kwadijk, 


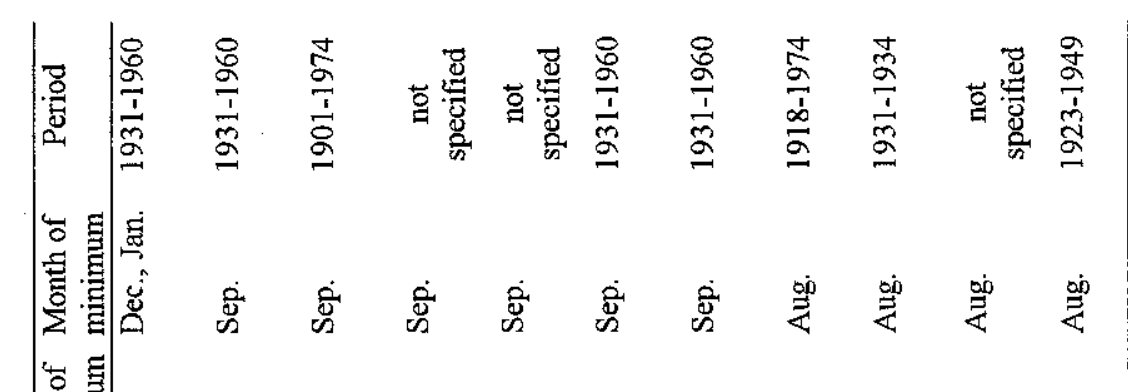

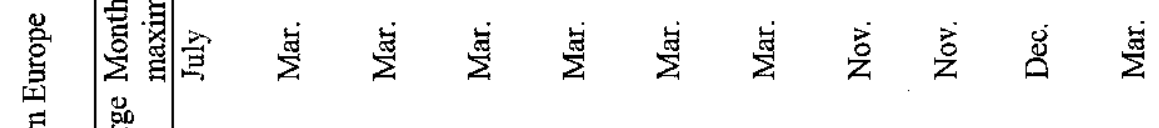

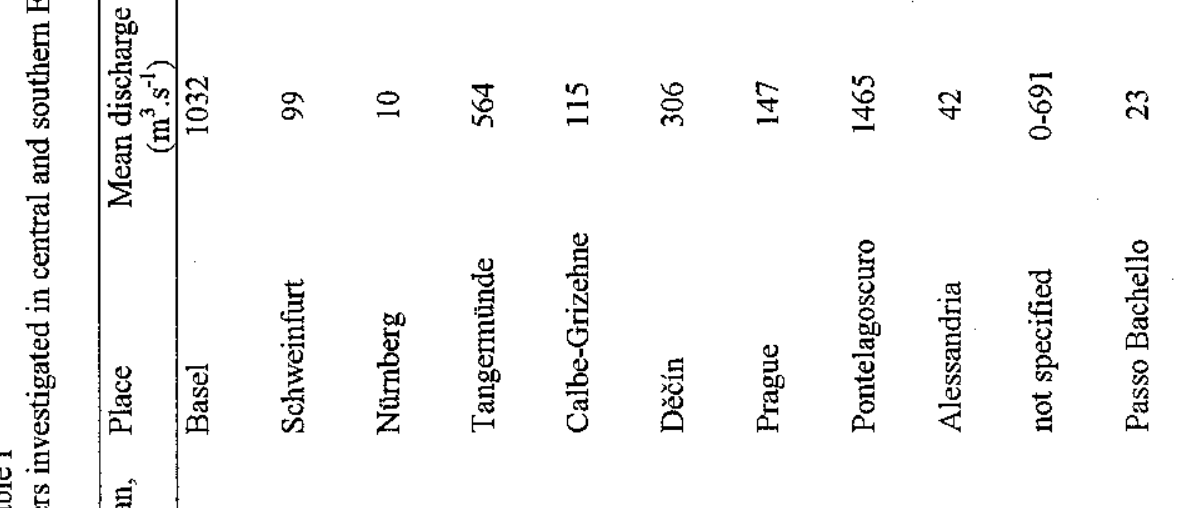
营

总

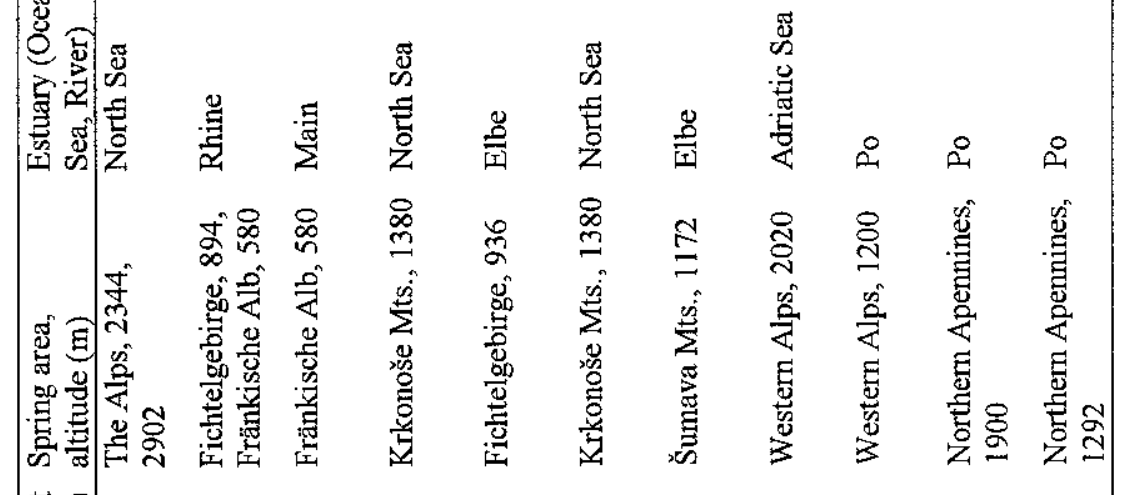

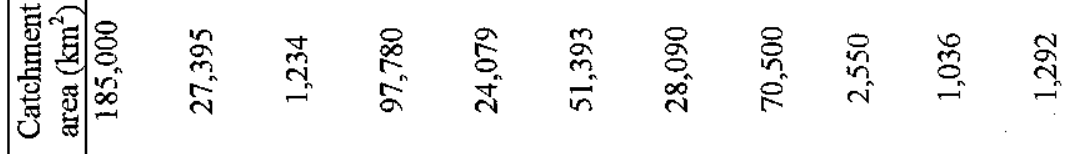

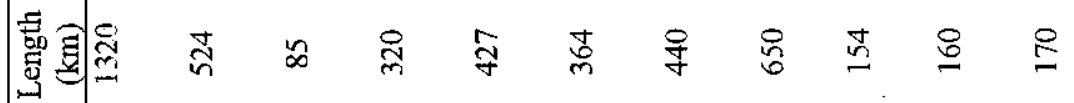
| 


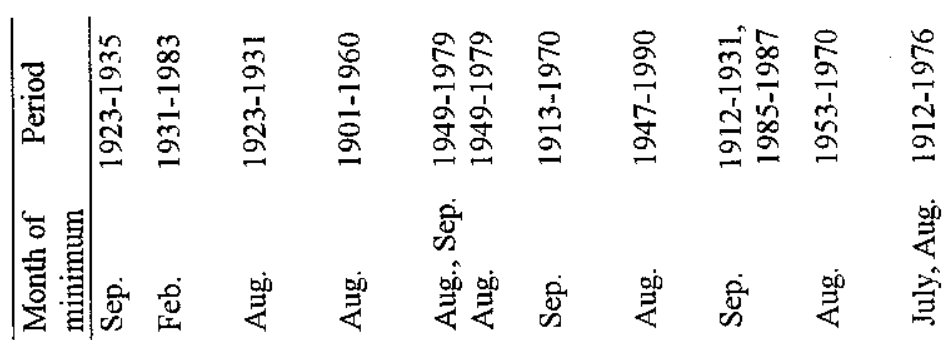

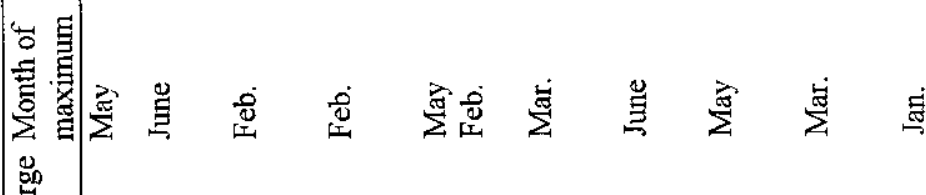

泡

急

焉兽

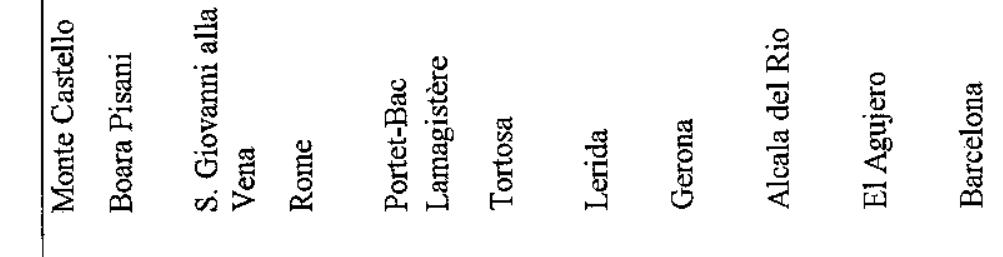

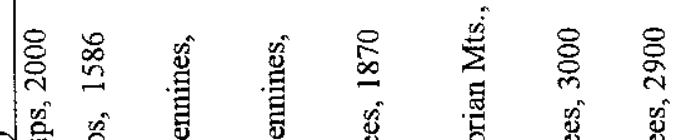

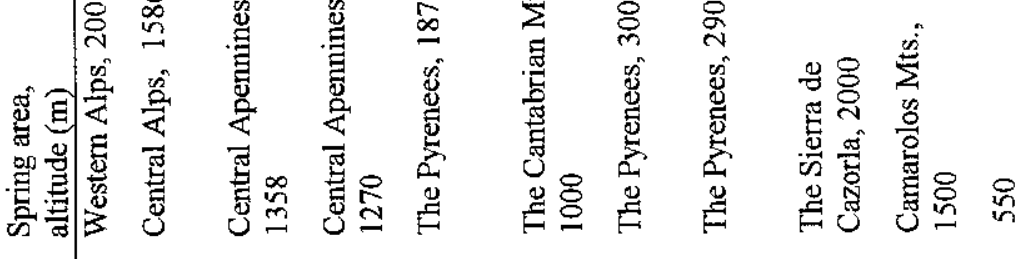

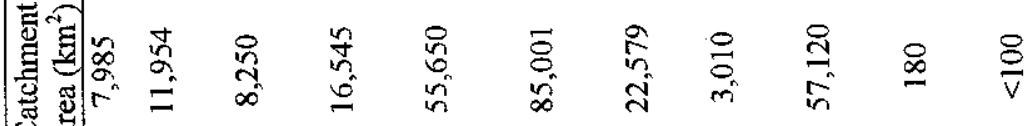

उु

㺃司究

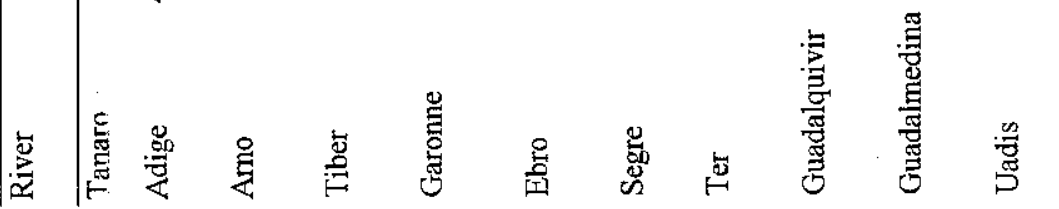




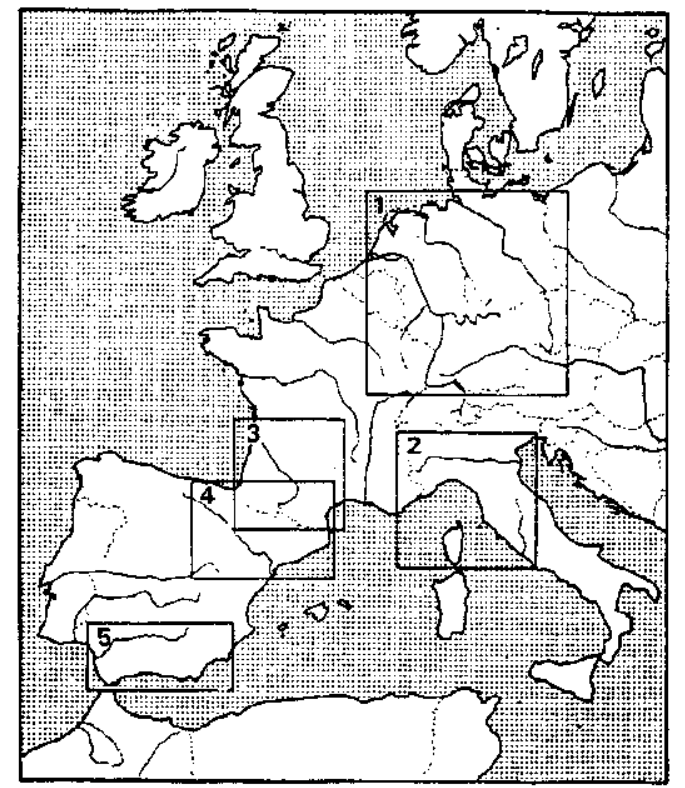

Figure 5. Location of map insets showing a more detailed position of the central and southern European rivers mentioned in this study (appurtenance to the given inset is always marked by the number in the upper left-hand corner).

1993). Lake Constance, which receives and regulates the flow of the Alpine Rhine, is known to be more sensitive to the volume of melting snow than to precipitation (Gasser, 1957).

b) Central European Rivers

Central European rivers in this study are from the catchment basins of the Main and Elbe rivers. The Main is a right-sided tributary of the Rhine in Germany. In it's upper part the Main is a typical upland or mid-mountain river, in it's middle part it is incised into a karstic limestone plateau and in it's lower part it flows through a broad lowland flood plain (Figures 5,6). The catchment area of the Elbe is divided into lower and middle parts in Germany and an upper part in Bohemia. It's upper part (Labe) is more or less delimited by the territory of Bohemia where the left-sided tributary, the Vltava (German: Moldau) contributes about $55 \%$ to the entire catchment basin. The middle part of the Elbe basin includes the section from the Czech border to the confluence of the Saale, the most important left-sided tributary. The middle part of the Elbe drains through more or less hilly or midmountainous regions of it's catchment basin prior to assuming the characteristics of a lowland river. The investigated rivers in central Europe are characterized by a maximum discharge in March and a minimum in August/September. The maximum discharge in March is the consequence of the melting snow cover which also causes a higher discharge rates in February and April. In the River Main in the western part of central Europe, winter precipitation also contributes to higher discharges during December and January 


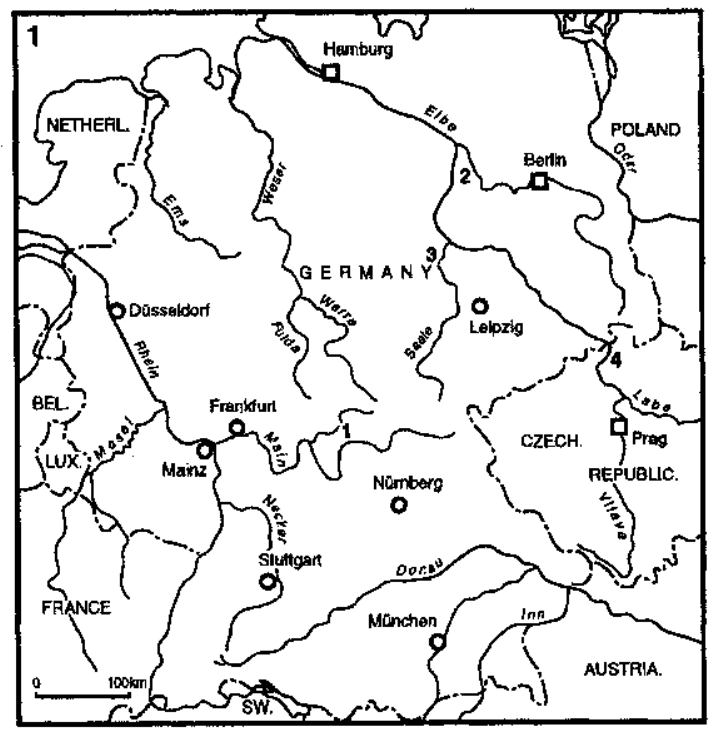

Figure 6. Catchment areas of the Main and Elbe. Water gauge stations: 1 - Schweinfurt, 2 - Tangermünde, 3 - Calbe-Grizehne, 4 -Děčín.

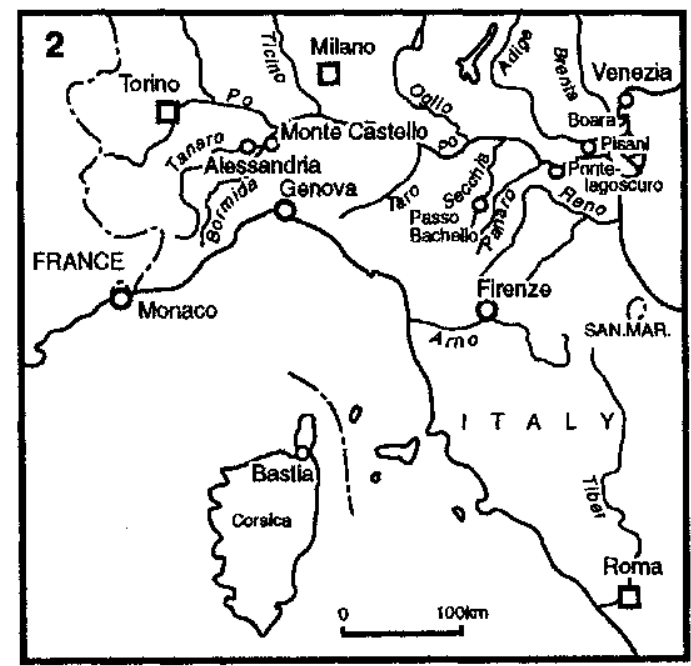

Figure 7. Catchment areas of rivers studied in northern and central Italy.

c) Northern and central Italian rivers

Eight northern and central Italian rivers are included in the study, namely, the Po and some of it's right-sided tributaries (Tanaro, Bormida, Secchia and Panaro), the Adige in northern Italy and the Arno and the Tiber in central Italy (Figure 7). Their minimum discharge rate occurs in August (the Tanaro in September) with the exception of the Adige where the minimum appears in February, In that same 


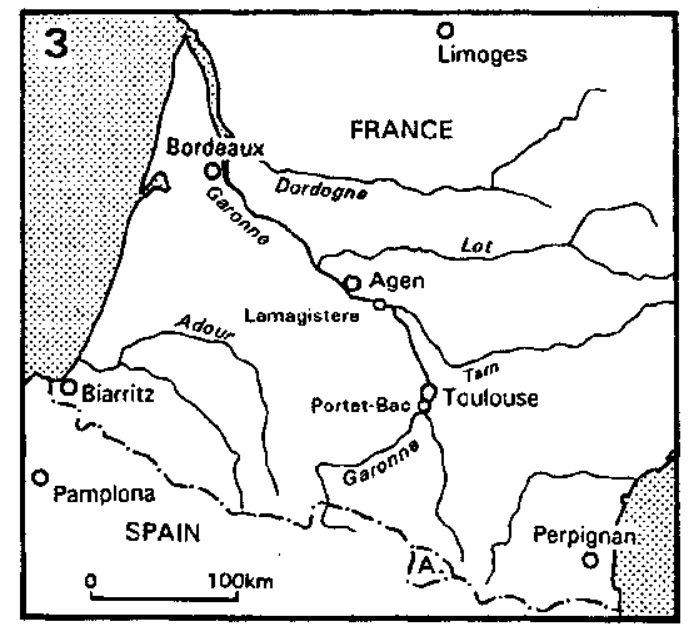

Figure 8. Catchment area of the Garonne.

month the Arno and the Tiber have a maximum discharge rate. Other rivers have maxima in different months: the Secchia reaches a maximum in March, the Tanaro in May, the Adige in June, the Bormida in November as well as also the Po, where the secondary discharge rate peak appears in May/June. The Panaro reaches it's maximum in December.

d) The Garonne

The left bank of the Garonne basin (40\%) extends into the Pyrenees and the surrounding foothill region. It's right bank extends into the Massif Central plateau area of south-central France and it's piedmont (52\%) (Figure 8). The Garonne discharges and floods are analyzed separately for the upper Garonne (Toulouse) and mid-Garonne (Agen) regions. Eighty percent of the water flowing into the Garonne in Toulouse is of Pyrenean origin (Gazelle, 1989). But in Agen 60\% of the water flow comes from rivers of the Massif Central and the surrounding foothills (as opposed to $34 \%$ for the Pyrenean waters and $6 \%$ for the waters of the central Pyrenean piedmont, i.e., the Lannemezan Plateau). In the region of the upper Garonne, the maximum discharge appears in May and higher values are also registered in April and June. In the mid-Garonne area the maximum appears already in February and higher discharge rates cover the span from December to May. The smallest discharge rate occurs in August and September.

e) Rivers of the Iberian Peninsula

Six rivers of the Iberian Peninsula (Figure 9) are included in this study. Four of them are located in Catalonia, namely the Ebro and it's tributary the Segre, the Ter and the Little Uadis (Catalan: Rieres) in Barcelona. The Guadalquivir and the Guadalmedina are located in Andalusia. The Ebro has the highest monthly discharges from December to May, the maximum peaking in March. The lowest discharges are recorded in September as a continuation of the dry period from July 


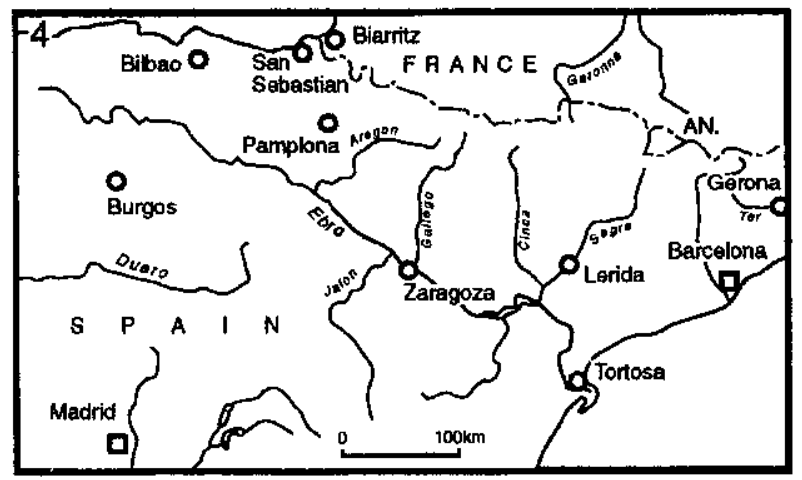

Figure 9. Catchment areas of rivers studied in the Iberian Peninsula.

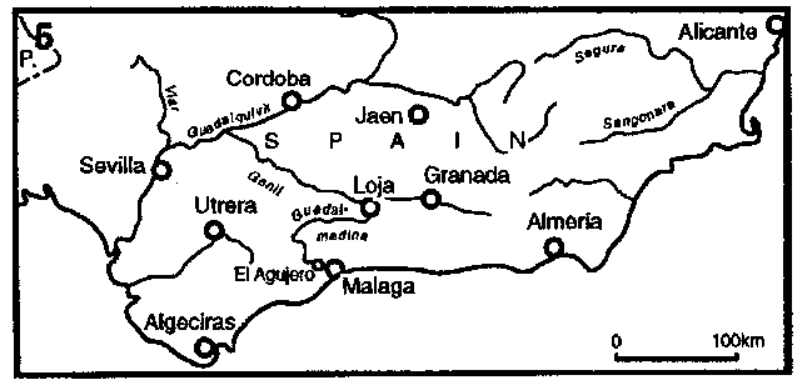

Figure 9. (Continued)

which is also the case of the two other Catalonian rivers. The maximum discharge rate for the Ter occurs in May during the period of higher values between March and June, while the highest values for the Segre occur in May and June with a maximum being reached in June. The spring or June discharge maxima of the Catalonian rivers are connected with the snow melting in the Pyrenees without floods. On the other hand, Andalusian rivers have the highest discharge rates during the period December-April (the maximum of the Guadalquivir being attained in March and that of the Guadalmedina in January) and lowest values from June to October (the Guadalquivir drops to a minimum in August, the Guadalmedina even dries up in July and August).

\section{Regional analyses of floods in selected areas of Europe}

Detailed written evidence about floods of selected rivers allow flood series to be compiled and arranged according to their causes as well as their impacts. The following simplified classification is suggested for distinguishing the weather patterns preceding flood events: 
a) heavy rain (downpours, cloudbursts)

b) continuous rain (of longer duration)

c) warming with melting snow and/or ice drifts (sometimes connected with rain)

d) no stated cause.

The described causes of floods can also be considered as, for example, in class c above. Floods resulting from the breaking of dams or embankments can usually be included among one of the first three groups when they are not related to war action. Information about the state of soil (dry, wet, or frozen) might be important when considering flood origins but it is usually only available in a few cases.

Details from the source material indicating the type and degree of damage allow flood events to be classified into three classes:

- Class 1: Small, regional flood; brief period of overflow; minor damage caused (e.g., to fields close to the river bank, stored timber being washed away, minor damage to buildings near the river, etc.).

- Class 2: Above average or supra-regional flood; brief period of overflow; little damage to hydrological structures (e.g., dams, locks, etc.), bridges and landings, buildings close to the river (e.g., water mills) and fields adjacent to the river bank; loss of livestock.

- Class 3: Above average supra-regional flood on a catastrophic scale; overflow for days or even weeks; severe damage to hydrological structures (e.g. dams, locks, etc.), bridges and landings, buildings close to the river (e.g. water mills), buildings at some distance from the river, fields adjacent to the riverbank; largescale loss of livestock; morphodynamic processes causing damage to fields for long periods, even years.

In addition to the causes of the floods and the class of damage, floods are also classified as to the time of their occurrence according to the seasonal division of the calendar (winter: December - February, spring: March - May, summer: June August and autumn: September - November).

Analysis results are generally presented on a decennial basis with respect to the mutual comparability of the individual rivers, the expression of the general features of the time occurrence of floods and also with the objective of preserving the linkage to other papers particularly devoted to the analysis of precipitation conditions in the sixteenth century (Glaser et al., this volume; Pfister and Brázdil, this volume).

\subsection{FLOODS OF CENTRAL EUROPEAN RIVERS}

\subsubsection{The Rhine River}

The first water gauge on the Rhine in Basel was established in 1808 in the vicinity of the old bridge. Historical flood information prior to that time arises from physical high-water marks as well as from published and manuscript documentary records from chronicles (Pfister, 1985, 1988). A set of 11 marks survived in Basel 
on the wall of the so-called Schönbein house situated not far from the site of the first gauge near the old bridge. According to these marks, four extreme floods were recorded during the period 1641-1881: 1876, 1852, 1801, and 1641. However, documentation of the number of extreme and severe floods with high-water marks between 1641 and 1807 is not complete. Furthermore, it is not known as to what extent the architectural point on the building was affected by subsidence and how the shape and depth of the channel was altered during this 240 year period. Nevertheless, according to the high-water marks three groups of events can be distinguished: extreme floods (marks $>60 \mathrm{~cm}$ ), severe floods (marks 30-60 cm) and minor floods (marks $<30 \mathrm{~cm}$ ).

Written reports describing floods of the Rhine in Basel go back to the Middle Ages, although they are only sporadic prior to the early sixteenth century. Floods were described in relation to a fixed threshold level of perception (Frances et al., 1994). In Basel, as in other places, this threshold level was linked to the presence of water in the streets and to the damage associated with it. An approximate scale of the magnitude can be deduced from the generic expressions used to define the five levels of a flood's magnitude:

- Level 1: Water covered the streets along the river as far as the corner of the Crown Inn near the ships landing. No damage occurred.

- Level 2: Water flowed onto the fish-market square and flooded the basements of the houses around it.

- Level 3: The water could be reached by hand from the windows in the house at the landing-place ("Schifflände") and it flowed into the lowest parts of the ancient fortification ("Zinnen") on the opposite bank of the Rhine.

- Level 4: Water could be ladled from the bridge with a scoop. The bridge was in imminent danger of being swept away.

- Level 5: Parts of the bridge were destroyed or damaged.

The descriptions, of course, are not strictly compatible with high-water marks or gauge readings. Nevertheless, they represent a valid subjective scale of flood magnitude. A level 5 flood never occurred during the measurement period inasmuch as a partial destruction of the bridge is not known from that time. Level 4 roughly corresponds to the extreme events and levels 3 and 2 to the severe events, i.e., the river flowed through the lower parts of nearby buildings. Level 1 events were not systematically recorded except by keen observers.

Fifty percent of the extreme and severe floods of the last 500 years occurred during the summer months, mainly in July (33\%). The long-term disposition of these floods is related to an unusually large amount of snow storage in the Alps or to a long phase of rainy weather that leads to the soil becoming saturated. On the other hand, $23 \%$ of the floods occurred during the winter months, mainly in December. Inundations in the cold season occur if a deep snow cover in the lowlands is rapidly melted by a warm south-westerly airflow associated with heavy precipitation. This occurs most frequently in the context of the so-called 
"Christmas thaw". In the sixteenth century three cases of December floods (1506, $1570,1589)$ are known to have occurred, two of which, those of 1570 and 1589 , were extreme.

The series for the Rhine in Basel is thought to be reliable for the period after 1510. The observations of the chroniclers from that town quite accurately mirror the extreme floods of major tributaries (e.g., the Aare and the Alpine Rhine) and related lakes (Lake Constance, Lake Zürich, Lake Lucerne) which are described in other sources. The approximate magnitude of six floods $(1506,1511,1560,1566$, 1570 and 1589) can be assessed for Basel because the chroniclers referred to one or several of the points of reference in the surroundings mentioned above. The magnitude of the events of 1584 and 1585 was estimated from other sources. An additional event is known from the diary of Joachim von Watt (Vadianus) who reported very high levels of Lake Constance and of the Rhine, presumably upstream from Basel in July 1515 (Götzinger, 1879). This is consistent with the observation of a severe, week-long flood in the vicinity of Strasbourg downstream from Basel (Weikinn, 1960). It is less clear whether the floods of 1529, 1542 and 1577 mentioned by the Basel chroniclers were large enough to be included in the list of severe floods (> level 2).

On average, severe floods occurred every 7.7 years in the sixteenth century. A distinction must be made between two sub-periods of high and low flood activity:

1. During the period with high flood activity, 1500-1515, one event was recorded every 4-5 years.

2. In the period of low flood activity, 1516-1559, just two events of lesser severity are known. With the exception of the twentieth century, this is the longest period of low flood frequency in the record. In order to better account for this pattern it should be noted that the climatic conditions during the period 15161559 were quite similar to those of the period 1901-1960, except that winters tended to be somewhat colder and summers somewhat warmer and drier (Pfister, 1992). This result has some implications for the discussion on the rare occurrence of severe mid-twentieth century floods which are generally attributed to man-made modifications. Although large areas in the Alps and in many hilly zones were reforested and, prior to the $1960 \mathrm{~s}$, artificial reservoirs were built in the Alps, the surface consumed by construction doubled from the 1950 s. That may have increased the run-off (Pfister, 1988). However, low frequency of floods in the period 1516-1559, during which the physical properties of the catchment areas were still entirely shaped by natural forces, raises the question as to whether the low frequency of floods in the mid-twentieth century might not be related to climatic change rather than to man-made modifications of the basin, especially when noting that the climatic conditions were somehow similar in the mid-sixteenth and in the mid-nineteenth centuries.

3. The third period, 1560-1585, stands out by its extraordinary high number of severe floods (one event every 3.7 years) both in summer and in winter. This 
might be related to a higher volume of melting snow (considering the large number of wet winters and springs), probably in combination with major thunderstorm activity in mid-summer. The highest total run-off of the Rhine near Basel during the last 500 years was reached in the summer of 1566. The most spectacular volume of snow accumulation at altitudes between 1000 and $2000 \mathrm{~m}$ known since 1500 was reached in the winter of $1565 / 66$. The snow cover increased during a long cold and wet spell in April. When the thaw began in May the lakes bordering the Alps quickly rose to a high level. A first peak discharge of rivers at the end of June lead to the partial destruction of many bridges, and the low-lying parts of cities such as Zürich and Lucerne as well as many villages were completely inundated. During a second peak in mid-July the level of the Rhine at Basel rose even $30 \mathrm{~cm}$ higher than during the first one. This led to a partial collapse of the bridge indicating a peak discharge estimated at more than $5700 \mathrm{~m}^{3} . \mathrm{s}^{-1}$ (level 5) which has never been recorded during the instrumental period. High-water marks in Lindau (Germany) suggest that the level of Lake Constance may have been even higher than the peak level during the summer of 1817 (Kobelt, 1926) following the famous year without a summer (Harington, 1992)

4. With only two events, flood frequency was again quite low during the fourth period 1586-1599. This seems to be in contradiction with the fact that rainfall in the summer during that time period was the highest over the last 500 years. But this estimate was mainly obtained from the high number of days with rainfall in summer registered by Renward Cysat in Lucerne. In this context he mentions the rare occurrence of thunderstorms and the high frequency of "cold rains" as being one of the striking features of this period. This suggests that many of these "rains" were of rather short duration and intensity and were associated with north-westerly and westerly weather situations.

\subsubsection{The Main River}

Fifty-three floods with discharges $\geq 800 \mathrm{~m}^{3} . \mathrm{s}^{-1}$ were recorded at Schweinfurt for the River Main during the instrumental period 1845-1964 (Keller, 1979). They were concentrated in the months from November to April (with a maximum in February) as a result of continuous winter precipitation often combined with melting snow. In the other months of the year floods were observed only in June, although the highest flood reported in the history of the river was in July 1342 (see e.g., Bork, 1988). The flood discharge of the Main is largely determined by the contributions from the upper Main and Regnitz drainage areas. Due to their different geomorphological character the run-off patterns of both areas are quite different. Whereas the floods of the upper Main region react almost immediately to weather events, the extended limestone karst areas in the Regnitz watershed have a dampening and retarding effect on the flood discharge. The discharges of the upper Main and the Regnitz at medium flood level are almost identical. Only below the 

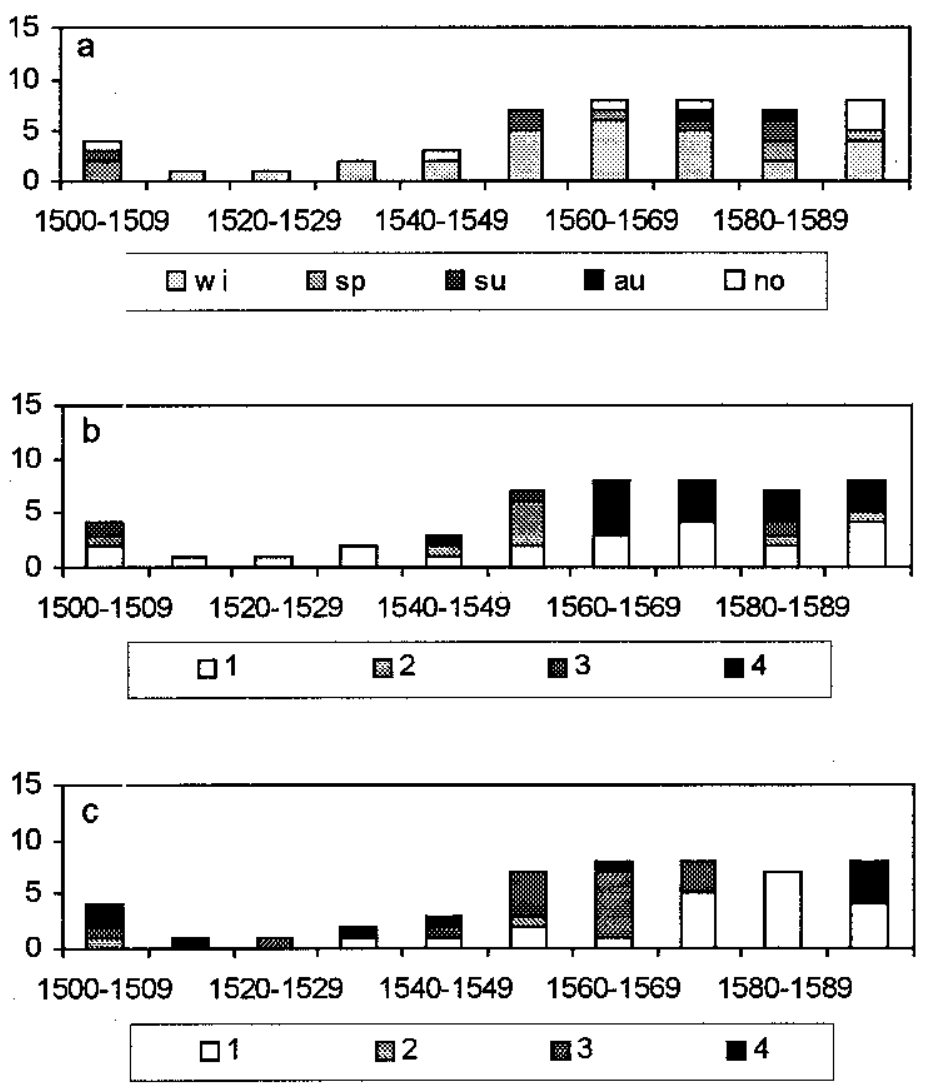

Figure 10. Decennial frequencies of floods on the Main with an indication of seasonality (a), their causes (b) and class of damage (c) during the sixteenth century. Explanation: seasonality: wi - winter, sp - spring, su - summer, au - autumn, no - without date; causes: 1 - no information, 2 - countinous rain, 3 - heavy rain, 4 - melting snow or ice drift; damage (see Chapter 3 ): 1 - no information, 2 - class 1, 3 - class 2, 4 - class 3 .

confluence of the Franconian Saale does the level become slightly higher again. The Saale and other small tributaries from the Rhoen and Spessart Mountains regularly produce their own melt water floods, but their crests tend to precede that of the upper Main. The run-off characteristics of the upper Main and the upper reaches of the middle part of the river totally determine the downriver run-off regime (Bayerisches Staatsministerium für Landesentwicklung und Umweltfragen, 1985).

Although data about floods were collected for each part of the Main separately, they are presented here for the entire river (Figure 10). As can be seen from the decennial frequencies of floods, there exists a dichotomy between their low values in the first part of the sixteenth century and high values in the second part, when their decennial distribution is more or less uniform. Fifty-seven percent of the floods were recorded in winter, followed by the same share of spring and summer 

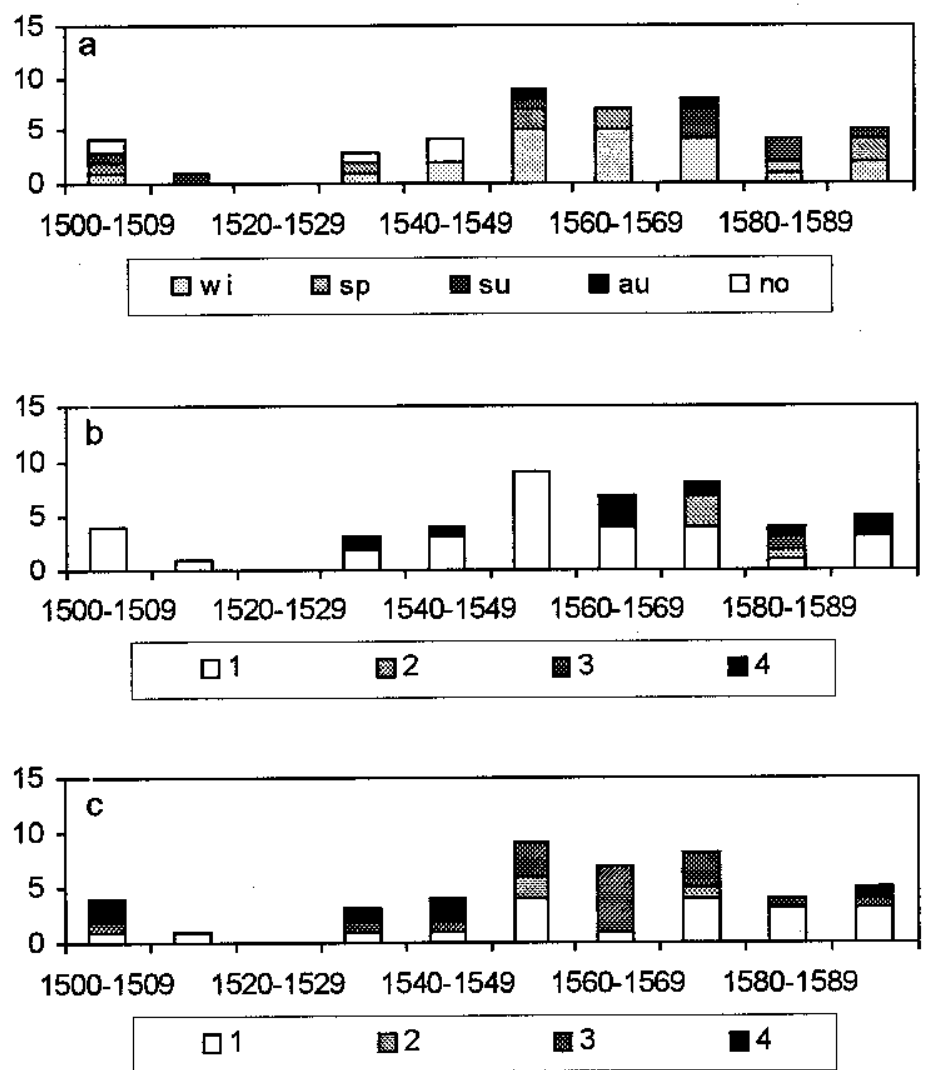

Figure 11. Decennial frequencies of floods on the Pegnitz with an indication of seasonality (a), their causes (b) and class of damage (c) during the sixteenth century. Explanation see Figure 10.

floods ( $12 \%$ each). The reason most often stated for the 49 recorded River Main floods is melting snow and ice drift (33\%), however, causes are not given for $45 \%$ of the floods (further continuous rains $16 \%$, heavy rains $6 \%$ ). More than half of the recorded floods caused heavy damage, namely $20 \%$ in the category of class 3 and $33 \%$ in that of class 2 .

Similar features to the Main are also seen in its tributary, the Pegnitz, where 45 floods were recorded during the sixteenth century (Figure 11). Sources about floods in the Nürnberg archives allow a continuous time series to be established from 1300 A.D. onwards. Obviously, floods at Nürnberg became significantly more frequent between 1550 and the $1590 \mathrm{~s}$. A second peak is seen in the seventeenth century, more or less coincidental with the Late Maunder Minimum. Neither before nor thereafter were comparable flood levels reached. Due to flood marks still preserved in their original positions and to very detailed descriptions, these events could be related to the present river gauges and could thus be quantified. The Pegnitz floods occurred most frequently from the 1550 s to the 

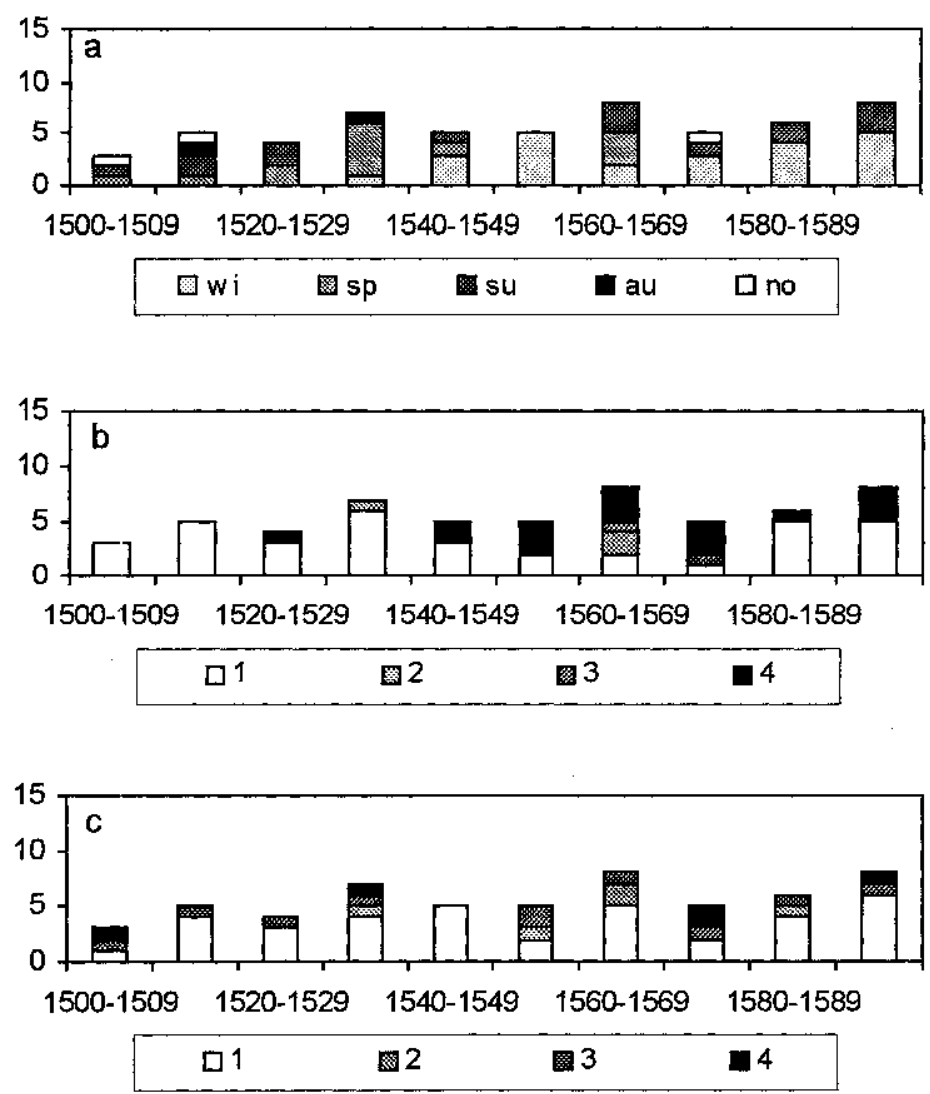

Figure 12. Decennial frequencies of floods on the middle Elbe with an indication of seasonality (a), their causes (b) and class of damage (c) during the sixteenth century. Explanation see Figure 10.

$1570 \mathrm{~s}$. Their frequency was lower during the last two decades of the sixteenth century. In $69 \%$ of all flood events, causes are not recorded in the written accounts while $20 \%$ were caused by the melting of snow and ice drift. As for the classification of damage, $13 \%$ fall within class 3 and $38 \%$ in class 2 . The Pegnitz shows similar seasonal divisions of the floods as the Main: $47 \%$ in winter and $20 \%$ in spring as well as in summer.

\subsubsection{The Elbe River}

Information about floods on the lower part of the Elbe is very limited (1567, March $1595,1598)$, therefore only it's middle and upper parts are included in this study.

\subsubsection{The Middle Elbe and the Saale Rivers}

The highest frequencies of floods of the middle Elbe are recorded in the 1560s and the 1590 s, followed by the 1530 s (Figure 12). Melting snow and ice drift are the causes of flood events in $29 \%$ of the 56 recorded cases, although for $63 \%$ of the 

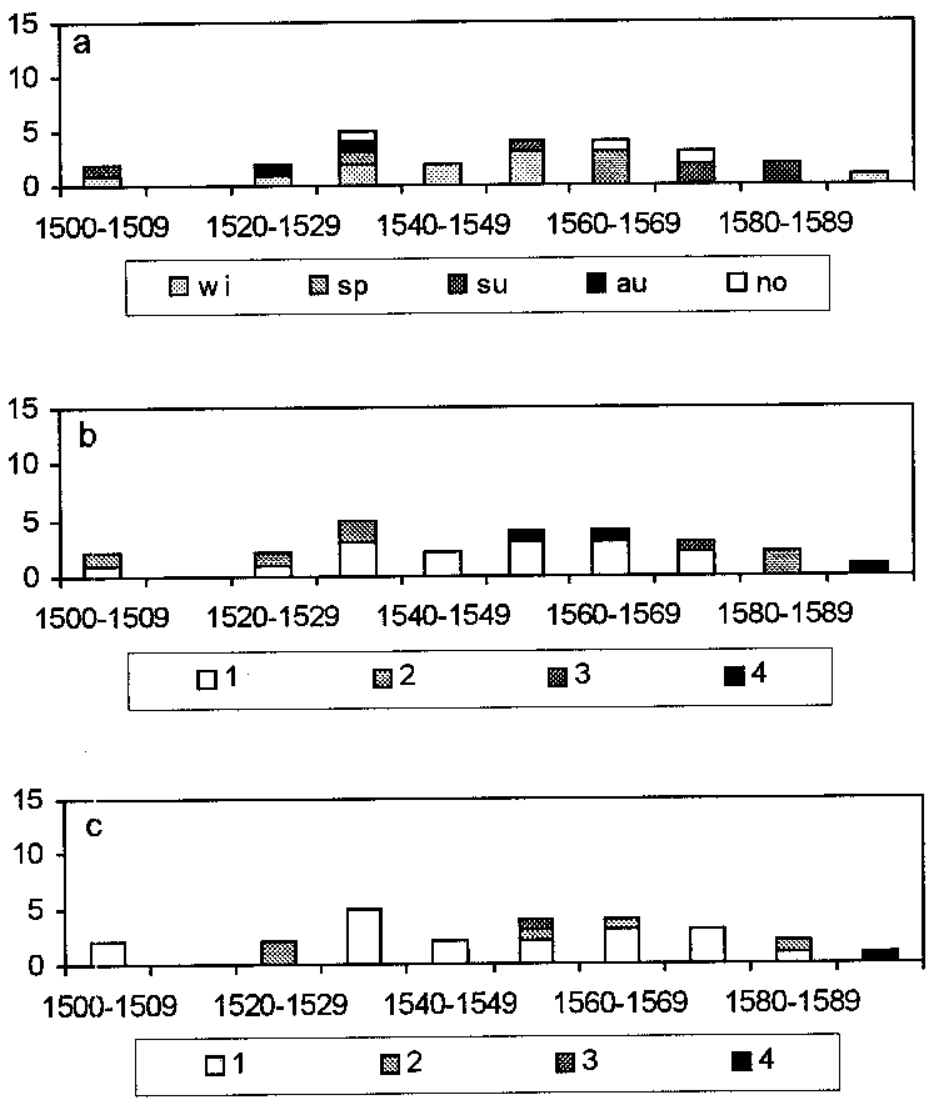

Figure 13. Decennial frequencies of floods on the Saale with an indication of seasonality (a), their causes (b) and class of damage (c) during the sixteenth century. Explanation see Figure 10 .

floods no cause is stated. As for classes of damage, $9 \%$ fall into class 3 and $18 \%$ into class 2 . Winter floods prevail on the middle Elbe ( $41 \%)$, followed by those in summer $(27 \%)$ and spring (23\%).

Only 25 floods are recorded during the sixteenth century on the Saale, the leftsided tributary of the Elbe in Germany (Figure 13). This probably does not express the total number of such events on this river during this period. Nevertheless, the highest frequency of floods in the 1530s and 1560s (as well as in the 1550s) is similar to that of the middle Elbe. The seasonal distribution of Saale floods is also similar to the middle Elbe: $40 \%$ in winter, $24 \%$ in summer and $16 \%$ in spring.

When considering the findings for these German rivers as a whole, a total of 13 floods of the Main, Saale and middle Elbe rivers during the sixteenth century are classified as supra-regional (see Chapter 3 ). This refers to floods that occurred in at least two of the three river systems at more or less the same time. Eight of these floods $(61 \%)$ took place during the winter season. Four of them $(31 \%)$ were 
summer floods. One flood was observed in May (8\%). Ten of the 13 simultaneously occurring floods (i.e., 77\%) took place in the second half of the sixteenth century (Table II).

A flood-mark in Halle/Saale (New Mill) shows the height of the most important severe flood event of the sixteenth century during the winter of 1594/95 reached in that town (Deutsch, 1993). During this very cold winter the first flood wave appeared after a sudden invasion of warm air and successive snow melting during the third decade of January. Moving ice floes and their blocking action caused damage and a rise of the water level in the rivers. Further floods followed in March 1595. The first of these inundations (2-5 March) was mainly triggered by melting snow in the lowlands (heavy snowfalls occurred in February) together with renewed ice drift. The next wave ( 8 March) was caused by long-lasting rains and melting snow from the mountainous regions. The great damage which occurred during this flood reached its final peak on 10 March. Similar floods in March 1595 were also recorded in the upper Elbe catchment of Bohemia.

\subsubsection{The Upper Elbe (Labe) River}

The first discharge measurements for the upper Elbe (Labe) at Děčin are from 1851. The upper Elbe floods at Děčin were analyzed by Kakos (1985) for the period 1950-1984. Among 31 floods (discharge rate $\geq 1295 \mathrm{~m}^{3} \cdot \mathrm{s}^{-1}$ ) a prevalence of winter events is seen from December to March $(65 \%)$ with a maximum in March $(19 \%)$.

Although historical information about the most severe floods and high-water marks for the Elbe at Děćin are not as good as for the Vltava at Prague (see Chapter 3.1.2.2.1.), Kotyza et al. (1995) compiled a series of severe floods from the fourteenth century based on data about flooded villages and churches and bridge damage. Beginning in 1432 marks of water levels on the castle rock above the right bank of the Elbe at Děćín could also be used. Of the 61 severe floods at Dièin, the five most extreme inundations with discharges estimated at $2900 \mathrm{~m}^{3} . \mathrm{s}^{-1}$ or higher are as follows (in the order of their severity): March 1845, July 1432, February 1805, February 1862 and August 1501 (Kotyza et al., 1995).

According to decennial frequencies of the historical floods of the upper part of the Elbe there is evidently a higher concentration of flood events from the $1560 \mathrm{~s}$, with the highest frequency being noted in the 1570s (Figure 14). An increase of floods causing severe damage in the aforementioned period is also seen. Of the 66 floods investigated, 12 are classified as class $3(18 \%)$. The most frequent causes of these floods is continuous rain (32\%) and melting snow and ice drift $(26 \%)$, although $35 \%$ of the cases were not classified (heavy rains $8 \%$ ). The number of summer floods was the same as in winter (33\% each). Twenty-six percent of the floods occurred during spring.

There is not a very good coincidence in the concordant occurrence of floods observed on the middle and upper courses of the Elbe. According to historical 
Table II

Overview of selected extreme sixteenth-century floods of different European rivers

The Rhine - Basel (13 floods)

December 1506, August 1511, August 1515, July 1529, August 1542, June-July 1560, all summer 1566 , December 1570 , June-July 1577 , July 1584 , August 1585 , December 1589 , June 1595

The Main, The Saale, The Middle Elbe (13 floods)

August 1501, February-March 1524, January 1546, February-March 1551, January 1552, January 1555, May 1563, March 1565, July 1569, February 1571 , July 1582, July 1584, JanuaryMarch 1595

\section{The Upper Elbe - Děčin (16 floods)}

August 1501, March 1504, May 1531, May 1537, December 1559, March 1565, February 1566, June 1569 , February 1570 , February 1573, January 1578, January 1579, January 1593, March 1595, March 1598, August 1598

The Vltava - Prague (13 floods)

August 1501, March 1504, July 1515, May 1531, May 1537, February 1566, June 1568, June 1569, February 1570, June 1582, May-June 1587, March 1598, August 1598

Northern and Central Italian rivers (13 floods)

October 1512, July -October 1520, October 1521, October 1530, May 1544, October 1544, MayJune 1547, August 1547, September 1557, October 1567, Autumn 1579, Autumn 1589, November 1595

The Garonne (Toulouse - T, Agen - A) (5 floods)

November 1522 - T,A, April 1523 - T, December 1537 - T, December 1598 - T, January 1599 $\mathrm{T}, \mathrm{A}$

The Ter-Gerona (5 floods)

December 1519 , October 1552 , October-November 1575 , October 1599 , November 1599

The Uadis - Barcelona (7 floods)

June 1500, March 1525, October 1542, October 1562, June 1578, July 1581, October 1591

The Ebro - Tortosa (2 floods)

September 1545, May 1582
The Segre - Lerida (5 floods)

The Guadalquivir - Sevilla (12 floods)

April 1504, November 1507, December 1544, January 1545, January 1554, November 1586, February-March 1590, February-March 1591, January 1593, January 1594, November-December 1595, January 1597

The Guadalmedina - Malaga (7 floods)

October 1544, December 1548, October 1554, December 1558, January 1561, October 1580 , October 1597 

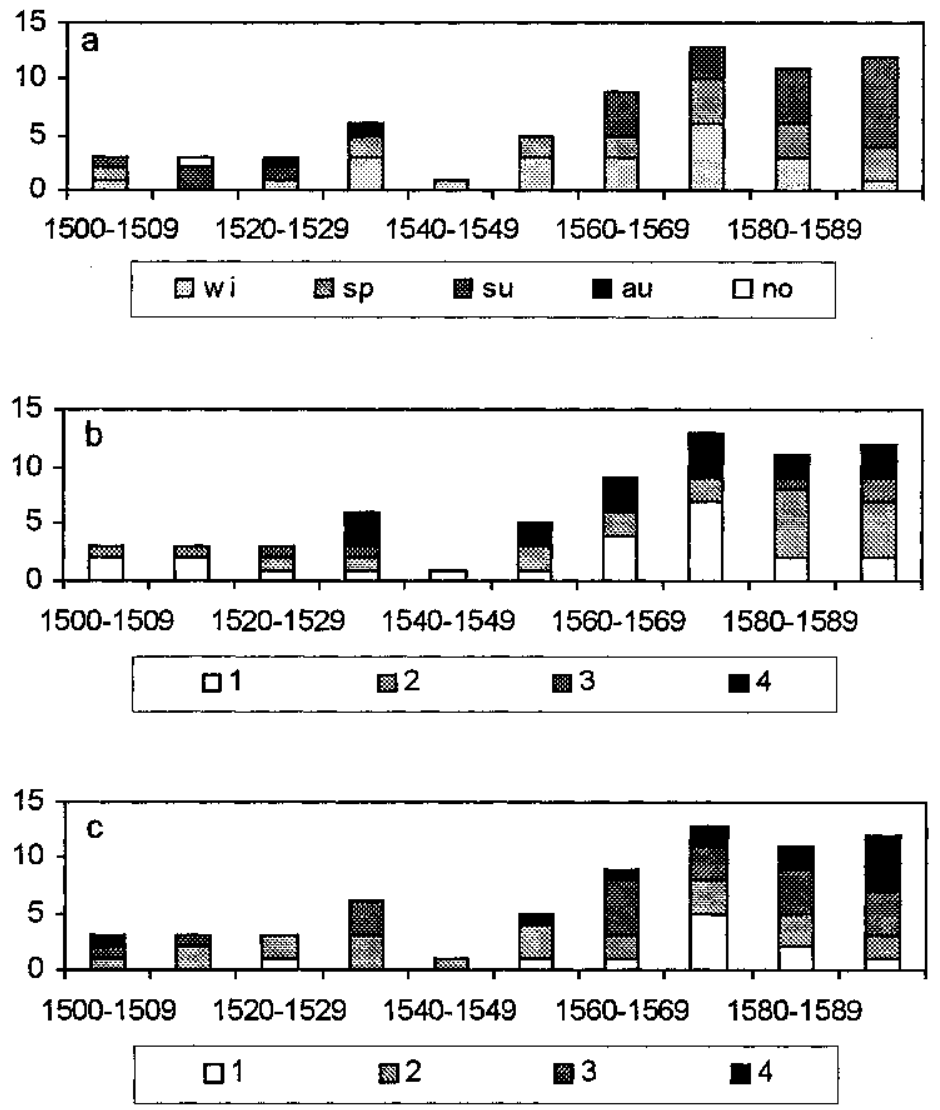

Figure 14. Decennial frequencies of floods on the upper Elbe with an indication of seasonality (a), their causes (b) and class of damage (c) during the sixteenth century. Explanation see Figure 10.

records, only $17 \%$ of all investigated floods were recorded on both parts of the river. Thirty-seven per cent of all floods were observed only on the middle course, $46 \%$ only on the upper course.

As the overview of severe floods during the sixteenth century (Table II) shows, only four severe floods (i.e., $25 \%$ ) were registered in the first part of the sixteenth century, whilst $75 \%$ were recorded between 1559 and 1598 . Severe floods occurred mainly in the $1560 \mathrm{~s}$, the $1570 \mathrm{~s}$ and the $1590 \mathrm{~s}$.

Of the 16 severe flood events, ten (i.e., $62 \%$ ) belong to the so-called winter synoptic type (Kakos, 1983, 1985, 1990) occurring only between November and March. This type is characterized by positive temperature deviations on the days preceding the culmination state, the watershed of the Elbe lying prevailingly in the warm sectors of several advancing depressions with warm advection from the west or south-west and a subsequent rapid thaw of the snow cover. The remaining six flood events (i.e., 38\%) belong to the so-called summer synoptic type (Kakos, 1983, 1985, 1990). This situation, occurring only from April to October, is 
characterized by negative temperature deviations on the days preceding the climax of a flood, when the catchment area of the upper Elbe is situated almost exclusively in the cold sector of a depression. In those cases depressions either proceed near the surface from northern Italy north-eastwards across Moravia and western Slovakia or they remain almost stationary over Poland. The position of these depressions allows the surface invasion of cold air from the north over central Europe. On the other hand, an upper depression with it's center over northern Italy and Hungary causes upper advection of warm air from the south-east. All this results in a sharpening of the frontal interface and convergence and subsequent ascent at the front, whereby precipitation in the vicinity of the front is intensified. Since the frontal interface runs either parallel to the upper flow or is slow-moving and/or retrograde, precipitation forming in the frontal zone has a continuous character (Brádka, 1967). Similar synoptic patterns caused the flood catastrophe of July 1997 in the Czech Republic and on the Oder River in Poland and Germany. For example, precipitation in northern Moravia during only four days (5-8 July) was double or triple the long-term July average (e.g., Mt. Lysá hora station, 1324 m, recorded $570 \mathrm{~mm}$ which is $289 \%$ of the $1961-1990$ July mean).

\subsection{The Vltava River}

The first water gauge was established on the Vltava in Prague (Praha) near the Old Town mills in 1825. Kakos $(1983,1990)$ investigated floods of the Vitava at Prague for the period 1873-1982. Of 36 observed floods (with a discharge rate $\left.\geq 1490 \mathrm{~m}^{3} \cdot \mathrm{s}^{-1}\right)$, the number of floods associated with the summer and winter synoptic types were more or less equal ( $44 \%$ and $42 \%$, respectively, $14 \%$ being of the indefinite type). These floods occurred in all months with a maximum in March ( $25 \%$ of all floods). The Vltava floods at Prague were considerably reduced after the building of a cascade of dams in the 1950s (Kašpárek and Bušek, 1990).

As far as is known from the history of the river, the level of the Vltava floods was measured from the stone figure of a bearded head (the so-called Bradáč) set into the fortification of the right bank close below the Charles Bridge. By using these data and other reports about the level of water during floods in the city, Kotyza et al. (1995) compiled a series of high-water marks from 1118 A.D. In the order of their severity, the five most severe floods of the Vltava took place in July 1432, February 1784, March 1845, September 1890 and August 1501. Among the 63 severe floods with an estimated discharge rate higher than $2200 \mathrm{~m}^{3} \cdot \mathrm{s}^{-1}, 13$ floods in the sixteenth century are included (Table II). Five of the 13 severe floods (i.e., 38\%) occurred before 1540 and the remaining eight floods (i.e., $62 \%$ ) from the $1560 \mathrm{~s}$. Although the estimates might be partly biased by changes of the river bank in Prague (see Chapter 4.1) and by a variable density of documentary records during the last millennium, they give valuable information about the most severe floods during the sixteenth century. 

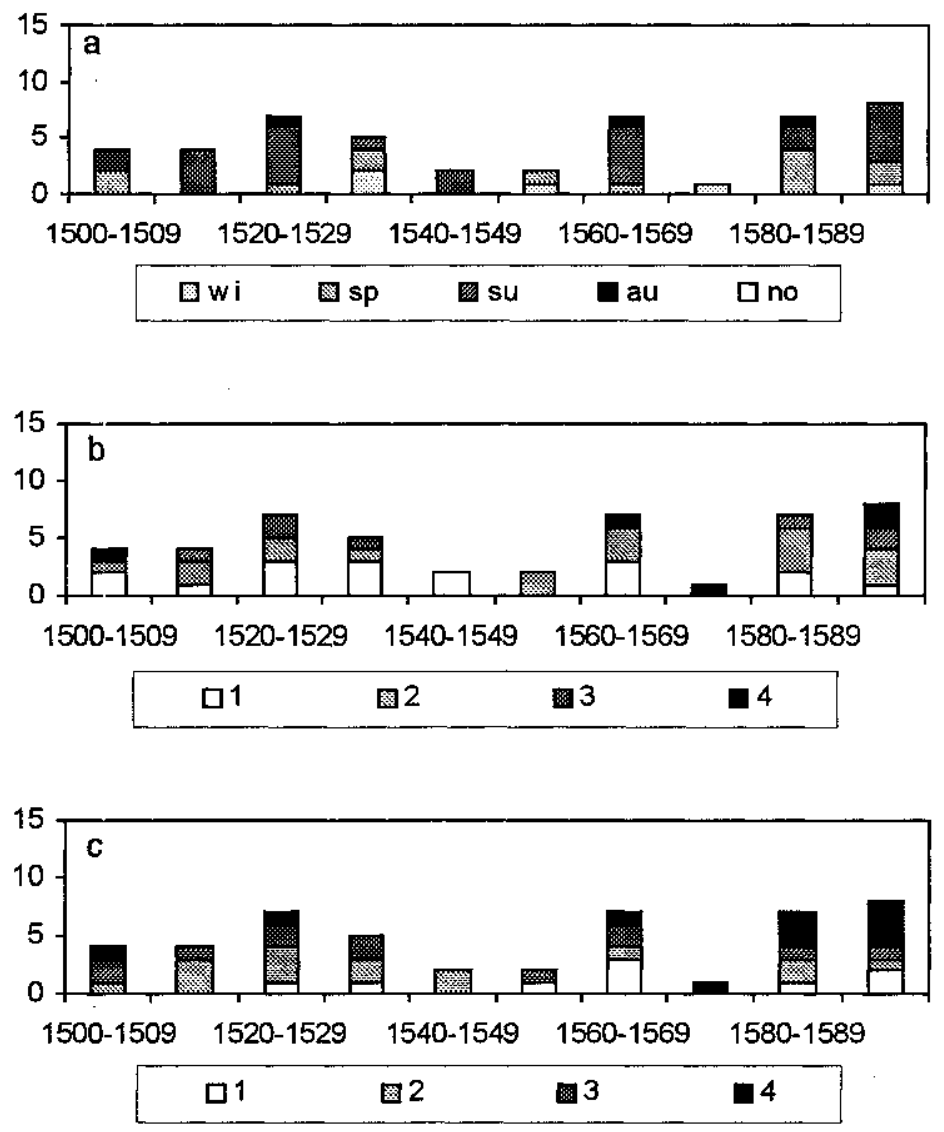

Figure 15. Decennial frequencies of floods on the Vltava at Prague with an indication of seasonality (a), their causes (b) and class of damage (c) during the sixteenth century. Explanation see Figure 10.

Of the 13 severe flood events, nine (i.e., $69 \%$ ) are of the summer synoptic type and only four (i.e., $31 \%$ ) can be classified as winter synoptic type. In comparison with the upper Elbe patterns as well as the Vltava instrumental records (Kakos, 1983), it becomes clear that the most important factor causing the most frequent flood events in the Vltava catchment is continuous rainfall.

Sixteenth century floods on the Vltava occurred with equal frequencies in the $1520 \mathrm{~s}$, the $1560 \mathrm{~s}$ and the $1580 \mathrm{~s}$ and more often in the 1590s (Figure 15). With regard to the upper Elbe only one observed Vltava flood during the $1570 \mathrm{~s}$ is surprising and that could be due to an insufficient amount of documentary evidence. Amongst 47 recorded flood events, continuous rains were the most frequent cause $(38 \%)$, followed by heavy rains $(15 \%)$ and melting snow and ice drift (11\%), although in $36 \%$ of these cases no causes were stated in the historical sources. Twenty-three percent of these Vltava floods caused serious consequences 
in Prague. Fifty-five percent of the floods occurred in summer, $28 \%$ in spring and $11 \%$ in winter.

The Bohemian flood of the century occurred in August 1501. Due to weeks of continuous rains a great flood wave arrived in Prague on 25-26 August when the Vltava level was one meter above the bearded head "Bradáč". Many ponds were breached; bridges, mills and houses were destroyed; wood and crops were carried away. These August rains probably fell over an extensive area. Floods on the above-mentioned days are also reported in Germany (on the Main, the Saale and the Elbe), Moravia and Silesia (Walawender, 1932; Weikinn, 1960).

\subsection{FLOODS OF ITALIAN RIVERS}

Documented flood events for northern and central Italian rivers (see Figure 7) are presented in Figure 16. There is an evident concentration of floods of all the investigated rivers in the first half of the sixteenth century. The highest flood frequency for the River Po was reached in the 1530s and the same frequency occurred during the 1500s and 1560s. A maximum of floods in the 1530s was also recorded on the Secchia, followed by the 1550 s and the 1540 s. Floods on the Tanaro culminated in the $1510 \mathrm{~s}$, but on the other two Po tributaries, the Bormida and the Panaro, only one or two flood events were observed during the remaining decades. Similarly, a low number of floods occurred on the Tiber (Camuffo and Enzi, 1996). Three floods were recorded during the first decade of the $1500 \mathrm{~s}$ and again in the 1540s on the Adige as well as during the first decade of the $1500 \mathrm{~s}$ and again in the 1550s on the Arno. An analysis of the distribution of flood events over the last millennium (Camuffo and Enzi, 1995, 1996) shows that the Adige, Po and Tiber flooded most frequently in the first part of the sixteenth century. The severity and scale of the Italian floods which occurred in that century is summarized in Figure 17.

In some cases many rivers flooded in the same year due to abnormal precipitation over a wide area (Table II). The most catastrophic floods, occurring simultaneously in many rivers, were recorded in October 1530 and September 1557. The areas affected were mainly northern Italy and, in the second place, central Italy. Southern Italy was hardly affected at all for various reasons. For instance, very few of the southern rivers have an extensive catchment area, precipitation is less frequent, and there is not the same wealth of documentation.

There were floods on the rivers mainly in the late spring and autumn. This is due to the bimodal nature of the precipitation that occurs particularly during the intermediate seasons when Atlantic disturbances can penetrate the region and Mediterranean depressions develop with sirocco winds. There were some rare cases of summer rains, e.g., in 1529,1547 and 1569 . No floods were recorded for the winter months of January and February which are generally dry. 
Po

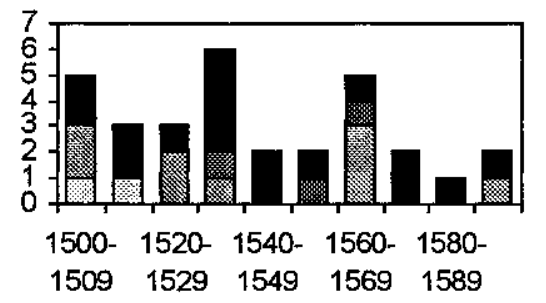

Bormida

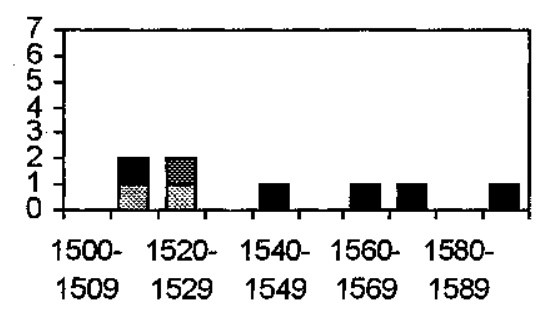

Panaro

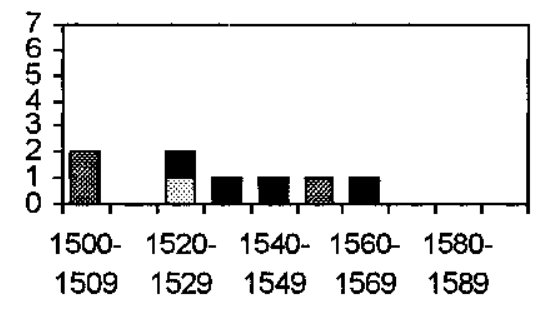

Arno

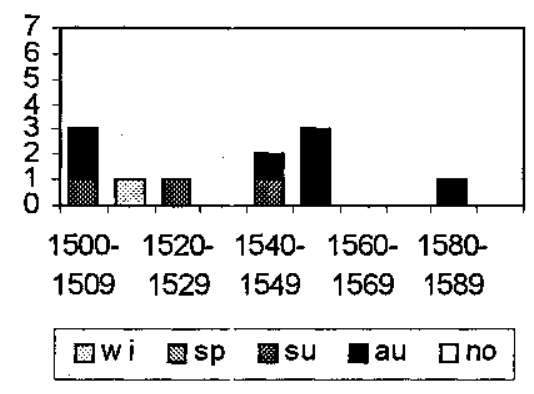

Tanaro
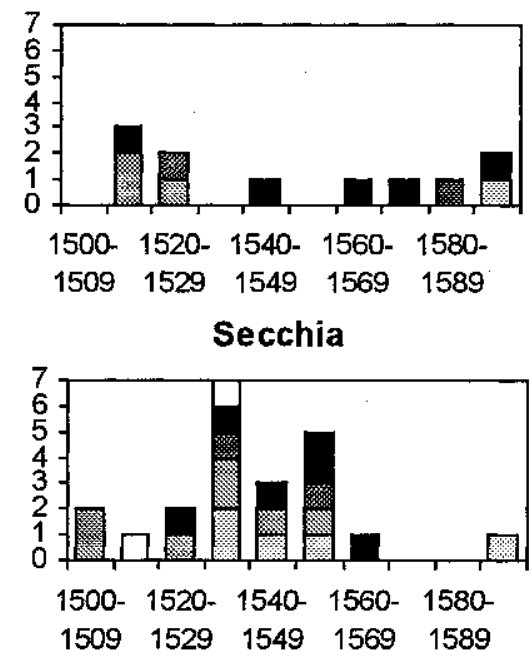

Adige

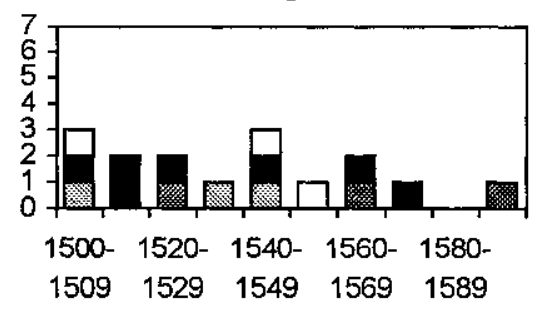

Tiber

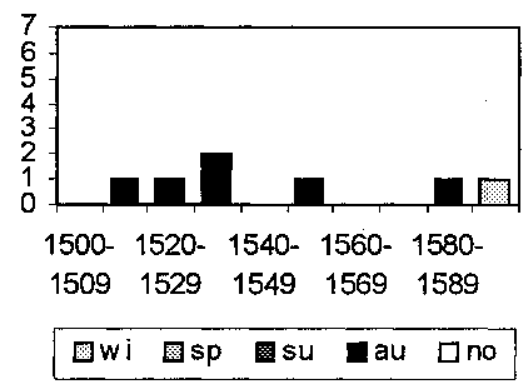

Figure 16. Decennial frequencies and seasonality of floods on the Po and its tributaries, the Adige, the Arno and the Tiber during the sixteenth century. Explanation: wi - winter, sp spring, su - summer, au - autumn, no - without date.

In late spring, melting snow from the Alps and Apennines adds to the rains. The spring floods destroyed crops and easily caused famine, since there was very little exchange of goods between neighbouring territories. 


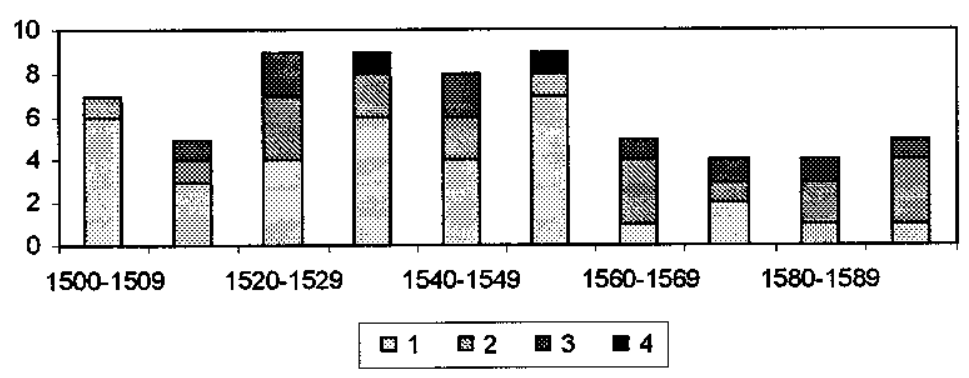

Figure 17. Decennial severity and scale extension of floods in northern and central Italy during the sixteenth century. Explanation: 1 - local, 2 - regional, 3 - large-scale or only one isolated catastrophe, 4 - large-scale and more than one catastrophe.

However, autumn was the most dangerous period. Due to a greater intensity and duration of rainfall and the fact that water tables were higher than in the spring, most of the rain would enter the rivers in a short time.

\subsection{FLOODS OF SOUTHWESTERN EUROPEAN RIVERS}

\subsubsection{The Garonne River}

Pardé (1935) distinguished between three main types of floods in the Garonne basin (see Figure 8) related to particular weather situations:

a) Pyrenean oceanic type

This is the most disastrous and frequent type of flood which is most likely to occur from April to June or even as late as mid-July. This type of flood is generated by considerable rainfall (about $200 \mathrm{~mm}$ per 24 or 48 hours) associated with north to north-westerly air streams that flow against the Pyrenean barrier. The mountainous northern Pyrenean basins are affected the most by rainfall totals increasing concurrently with altitude. The upper northern Pyrenean valleys down to Toulouse are then affected in priority. Although the Massif Central rivers are swollen a little, the overflow of the Pyrenean rivers may sometimes spread to the middle valley or even the lower valley of the Garonne down to Bordeaux (e.g., in April 1770 or June 1875).

b) Classical oceanic type

This type of flood occurs most likely between December and March or sometimes even early April. Associated with west to south-westerly air streams, rain spreads to the basin as a whole but more particularly to the southern and western foothills of the Massif Central and to the lower Garonne valley downriver from Toulouse. The northern slopes of the Pyrenees as well as it's piedmont benefit from a sheltering effect at the foot of the chain. Rainfall totals may reach 150 to $200 \mathrm{~mm}$ within four or five days. Although the water rise is slow, inundations last on the downriver course due to supplies from the Massif Central rivers (the Tarn and the Lot). 
c) Mediterranean type

This kind of flood is generally considered as a minor type in the Garonne basin and is most likely to occur from September to early November. Several weather types are associated with such a flood. When an eastward-moving Atlantic depression takes a more northern route over Spain, the flood-producing rain in the southerly flow which falls on the Spanish side of the Pyrenees may extend to the French side along the bordering crest. Heavy floods may thus occur in the upper Pyrenean valleys but they do not reach the piedmont (e.g., 7-8 November 1982). Generally, a typical Mediterranean depression forms and develops through the advection of warm and moist subtropical air converging on cold air originating from the north. In most of cases, this weather pattern is accompanied by the presence of an upperlevel cold pool that steepens the vertical temperature gradient. By flowing against the surrounding Mediterranean high ground, such an air stream generally generates heavy rain on the eastern margin of the Garonne basin, from the Cévennes in the north to the Pyrénées-Orientales department in the south. The upper valleys of the Garonne tributaries flowing from the Massif Central (e.g., the Tarn and the Lot) may thus be affected by rain and subsequent floods. Sometimes, the activity of these Mediterranean depressions spreads beyond the actual Mediterranean area. They may migrate north-northwestwards and then more directly affect the Tarn middle valley or even the Garonne middle valley. In both cases, the Ariége, the basin of which is at the junction of the oceanic and Mediterranean areas, may also be involved, particularly when this pattern is accompanied by the "east backlash" of air streams which flow against the northern side of the western flank of the Pyrenees (Vigneau, 1986). This type of Garonne flood, underestimated by Pardé (1935), was probably more frequent in the past than during the twentieth century.

There are abundant printed sources about historical floods in the Garonne basin used in studies by Champion (1864-1868), Marsan (1893), Serret (1900), Chalande (1912), and Antoine et al. (1991). Prior to the eighteenth century, these sources are often based on the chronicle compiled by De Lafaille (1682) which contains several mistakes for the period prior to the sixteenth century. The only critical work about Garonne floods is by Galabert (1918). From 1880 and with the generalization of hydrological measurements, reliable data and works are available (Pardé, 1935; SMEPAG, 1989), even though special care must be taken in comparison with older data.

The first reports about floods are in the eighth century at Agen and as early as the twelfth century at Toulouse. In the sixteenth century, there were ten floods in Toulouse, with the highest frequency in the 1540s (3 floods), and 16 in Agen, concentrated mainly between 1557 and 1580 (9 floods) (Figure 18). A Garonne flood in Toulouse is not necessarily echoed in Agen, and the converse also applies, thus clearly showing an independence of the two main feeding systems of the Garonne (the Pyrenees and Massif Central) when floods occur. There is a 

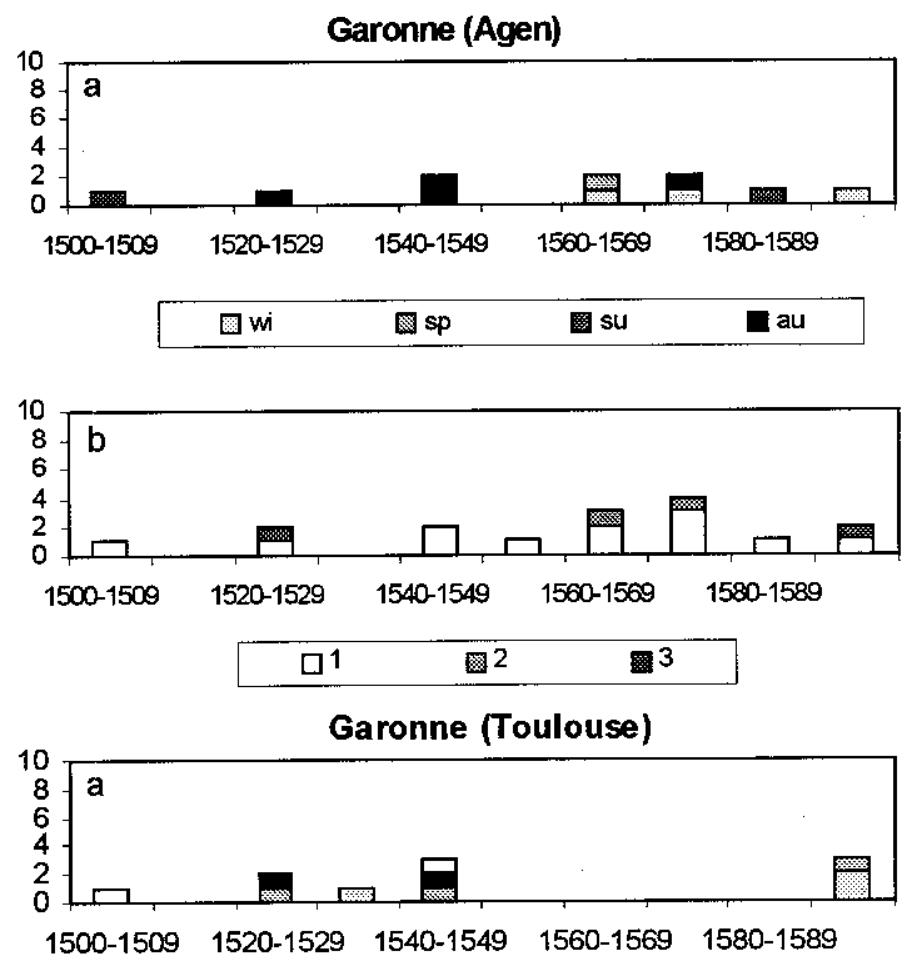

图wi 圈sp a su $\quad$ ano

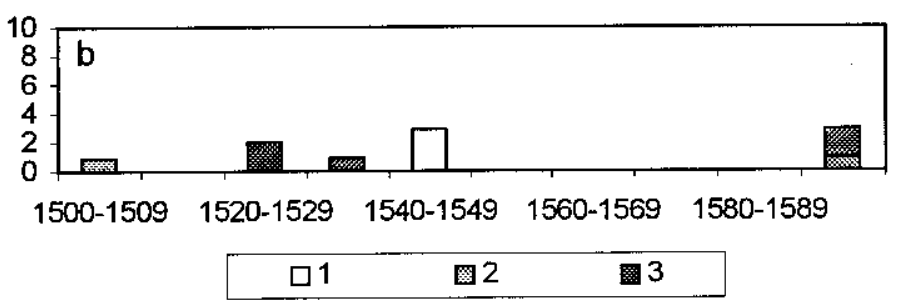

Figure 18. Decennial frequencies of floods on the Garonne at Toulouse and Agen with an indication of their seasonality (a) and severity (b) during the sixteenth century. Explanation: seasonality: wi - winter, sp - spring, su - summer, au - autumn, no - without date; severity: 1 - minor flood (minor damage or uknown power), 2 - medium flood (houses, mills or hydraulic factories damaged), 3 - severe flood (human victims, houses and bridges destroyed).

consistent increase in the frequency of floods in Toulouse and Agen from the thirteenth to the nineteenth centuries prior to a distinct decrease in the twentieth century. The first period of this evolution may reflect both a real increase of floods and a better recording of the facts in the archival sources. The possible effects of development and occupation of basins and banks (e.g., embankment, dyking, damming, reafforestation of mountainous slopes, and rural and mountain exodus) must also be taken into account to explain the reduced number and intensity of 
floods in the twentieth century. The magnitude of floods seems to be no more nor less acute than in the sixteenth century.

Five floods recorded in Toulouse may be deemed as major (houses and bridges destroyed, people drowned) while there were only two such floods in Agen. The greatest flood of the sixteenth century in Toulouse and Agen was in January 1599 (Lafaille, 1682-1701; Galabert, 1918, and Mateu, 1982). During this flood the Saint-Cyprien quarter in Toulouse was transformed into an "island", an event which had never been seen before. The small village of Montaudran near Toulouse was destroyed by the Hers, a Garonne tributary. In Agen, where this flood was called the "Great Deluge", the surrounding walls were destroyed, as well as 26-27 houses in the small village of Double near Agen.

The seasonal distribution of sixteenth-century floods in Toulouse and Agen seems different from that of the twentieth century (1900-1985), the seasons being defined as spring, April-June; summer, July-August; autumn, SeptemberNovember; and winter, December-March. Inundations steadily occurred in Toulouse in winter (four floods) and equally in spring (two floods) and autumn (two floods) in the sixteenth century (the season of occurrence is known for eight of ten floods), and mainly in winter (six floods) and spring (seven floods) in the twentieth century ( 15 floods higher than $2500 \mathrm{~m}^{3} \cdot \mathrm{s}^{-1}$ ). In Agen, floods also occurred in autumn (three floods) and winter (three floods) in the sixteenth century (the season of occurrence is known for nine of 16 floods), and solely in winter (nine floods) and spring (seven floods) in the twentieth century (16 floods higher than $4000 \mathrm{~m}^{3} \cdot \mathrm{s}^{-1}$ ). As may be seen in the first half and the second half of the sixteenth century, floods seem to occur mostly in autumn in Toulouse (two of four floods), and even more so in Agen (three of four floods) during the period 1500-1549. There is a sharp reverse in the period 1550-1599, with most of the floods occurring in winter, $75 \%$ in Toulouse (three of four floods) and $60 \%$ in Agen (three of five floods) (100\% for winter and spring in Toulouse, $77 \%$ in Agen).

It would appear that a shift from dominant autumn floods to dominant winter and/or spring floods took place in the sixteenth century. Despite the small size of the sample it seems worthy to be discussed in somewhat more detail. According to Pardé (1935) and SMEPAG (1989), winter or spring Garonne floods are most likely to be associated with the classical oceanic or Pyrenean oceanic types, while autumn floods are most likely to be linked with the Mediterranean type. Usually, the first type shows typical zonal circulation characteristics while the second type expresses meridional exchange in the atmospheric circulations, particularly of a subtropical origin. Therefore, the question is whether the apparent domination of Mediterranean floods in the first part of the sixteenth century and of oceanic floods in the second part could indicate changes in meteorological patterns. There would seem to be no doubt that the small number of the sixteenth-century floods does not allow a specific answer. But perhaps such would be possible if the floods of the 
sixteenth century were to be considered analogically to the general chronology of Garonne floods.

\subsubsection{Rivers of the Iberian peninsula}

The data on floods for Spanish rivers (see Figure 9) originate from the following cities: Tortosa for the Ebro, Lerida for the Segre, Gerona for the Ter, Barcelona for the Uadis, Sevilla for the Guadalquivir and Malaga for the Guadalmedina. The configuration of these cities remained virtually unchanged until the beginning of the modern epoch and the pronounced variations in water level are well reflected in the rich evidence produced within these urban environments. In Sevilla, Diego Ortiz de Zuniga, author of the Sevilla Annals, describes how human activities in the river (such as cleaning of the river bed, construction of channels and embankments) were neglected during the sixteenth and seventeenth centuries, thereby resulting in a high number of floods, most of which caused severe damage in urban areas (Babió Wall, 1990). Only the construction of dams during the twentieth century has altered the occurrence of floods in these localities. When the overflow of rivers caused serious damage to the fixed infrastructure and facilities (e.g. buildings, bridges, water mills, and embankments) in the towns selected, they were considered to be catastrophic floods. The flood damage provoked important economic crises, the rising of prices and shortage of goods being mentioned in royal letters by Philip II (dated 28 September 1579, 23 November 1583 and 20 May 1584), when the king answered requests of the town of Almeria on the Andarax River.

Corresponding information about floods was extracted from original municipal documents and urban annals. In some towns, such as Sevilla and Gerona, authorities gave sufficient information to reconstruct the water levels and determine the maximum level registered during flooding. But in most places the descriptions focussed on the damage caused by the floods and not on their hydrological characteristics.

\subsubsection{Rivers in Catalonia}

Hydrological characteristics are very different between the selected Catalonian rivers (see Table I), thus making it difficult to obtain a relatively balanced result. They present a very low frequency of severe floods with the following return periods: 46.4 years within a 650 -year period for the Ter, 44.1 years within a 617year period for the Ebro and 38.2 years within a 459 -year period for the Segre. Only the Uadis in Barcelona presents a higher frequency with 14.4 years for a 462year period. These records have been interrupted by the construction of dams, especially during the period, 1940-1970. Barcelona presents a very early interruption in the mid-nineteenth century because of the large urbanization around the old town (Barriendos, 1995b; Barriendos and Martín-Vide, 1998).

The overview of severe sixteenth-century floods on the selected Catalonian rivers is given in Table II. The first half of the century had very few floods, while 
the second half had more floods, especially in the 1590 s. In fact, an analysis of the last two decades of the century shows the beginning of an oscillation, which reached its peak in the early years of the seventeenth century and ended about 1620. Similar oscillations only appeared in the last decades of the eighteenth century (1760-1800) and the mid-nineteenth century (1830-1860) (Barriendos, 1994, 1995b; Barriendos and Martín-Vide, 1998). It was particularly critical in 1617 during the months of October and November when a spell of continuous heavy rainfall caused general flooding with very heavy damage all along the Mediterranean coast of the Iberian Peninsula and in the mountainous regions of Catalonia. The year 1617 became known as "the year of the flood" (Barriendos, 1995a).

The seasonal distribution of the sixteenth-century floods is characterized by the highest frequency occurring in autumn $(56 \%)$, medium frequency in spring and summer $(19 \%)$ and the lowest frequency in winter $(6 \%)$. Spring floods are the result of developing convective activity in coastal areas or melted snow added to rivers with sources in the Pyrenees (the Ebro in Tortosa and the Segre in Lerida). Summer floods are a product of heavy convective rains fed along the coast by warm and humid easterly airstreams from the Mediterranean Sea. The intensity of precipitation well exceeds the drainage capacity of the rivers, although the absolute total of precipitation is often quite low. Finally, autumn floods in Catalonia are caused by the passage of low pressure systems which are reactivated by the presence of warm and humid air still present at this time of the year in the Mediterranean. Extreme flooding also occurs in episodes of heavy rainfall caused by an upper-level cold pool over the Iberian Peninsula generated by the convergence of polar and tropical airstreams associated with a strongly meandering jet stream.

\subsubsection{Rivers in Andalusia}

The valley of the Guadalquivir, the main river in Andalusia, is an extensive lowland in the region that penetrates deeply into the interior from the coast. Seventeen floods were recorded in its basin in the period, 1900-1983. Fifty-three percent of them occurred in winter, $29 \%$ in autumn and $18 \%$ in spring (Font Tullot, 1988). The efficacy of the water reservoirs, irrigation channels and changes in the river beds near the main cities have contributed to diminished flood damage, although destructive floods have been recorded in the twentieth century in Sevilla (e.g., 2-5 March 1947 and 25 November 1961). Most of the floods in the Guadalquivir catchment are caused by continuous precipitation associated with Atlantic depressions and their attendant fronts which cross the region from west to east. These situations are more common in winter, although they may also occur in spring and autumn (Castillo Requena, 1989).

In the sixteenth century such a situation affected Seville during the floods in the cases listed in Table II. Other cities in the Guadalquivir catchment basin were also 
damaged by floods. The worst floods occurred in the $1590 \mathrm{~s}$, particularly in February 1590 with great damage in many cities, including Sevilla, Loja and Granada.

Types of weather causing floods in Sevilla often cover a large area on the Iberian Peninsula. Thus, other river basins to the north are also flooded, such as that of the Guadiana in 1544. In January 1565 the Tajo flooded in Toledo. In the winters of 1596 and 1597 there were also floods on the Duero in Castilla (Alvarez Vazquez, 1986).

Besides the Guadalquivir, southern Spain has many small rivers flowing from the mountains into the Mediterranean Sea forming part of the hydrological system in Andalusia. On one of them, the Guadalmedina, 14 floods were recorded in Malaga during the twentieth century, the most severe being in September 1904 and 1907 and in November 1989. The meteorological causes of these floods are torrential rains, convective in nature, occurring in the autumn, which is typical of Mediterranean weather patterns (see Chapter 3.3.1). At the end of the autumn and in winter, rainfall connected with Atlantic depressions is the main forcing factor in the Guadalquivir catchment. In addition, the geographical location of Malaga, surrounded by mountains with steep slopes, contributes to the water-flow violence. Moreover, in the sixteenth and seventeenth centuries trees on the slopes were cut down and replaced by vineyards which resulted in a more intensive surface run-off and soil erosion (Colosía Rodríguez, 1978).

The main inundations in Malaga during the sixteenth century (Table II) flooded the city and the surrounding agrarian lands, causing loss of life, destroying houses, ditches, harvests, stores and ships in the port of the city.

The decennial frequencies of Andalusian floods show that there is a clear maximum during the $1590 \mathrm{~s}$ with secondary peaks in the $1540 \mathrm{~s}$ and $1550 \mathrm{~s}$. No severe floods were recorded during the second, third and fourth decades of the sixteenth century nor in the 1570 s. This distribution corresponds with precipitation indices for Spain in the sixteenth century (see Glaser et al., this volume).

\section{Discussion of results}

\subsection{ANTHROPOGENIC MODIFICATIONS OF THE RUN-OFF PROCESS}

The run-off process of a catchment basin and its flood events are greatly influenced by changes in the character of the landscape. The last millennium, including the sixteenth century, was characterized by the intensification of human influence on nature and its features. On the one hand, there are impacts related to land-use changes connected with agriculture and other sectors of the economies directly influencing the run-off process (e.g., deforestation or afforestation, drying of wetlands). On the other hand, however, there are direct changes in the river bed 
and water management (e.g., regulation of rivers, building of water structures, use of water for industry and irrigation). Because of the lack of correspondingly exact data for the past and the impossibility of determining the characteristics of each of the rivers investigated above, only a few examples of human influence are mentioned.

Such an influence can be illustrated by the example of the Po, where the hydraulic regime is governed by waters descending from the Alps and the Apennines. During the sixteenth century, the population growth in Italy resulted in the spread of arable land into hilly and mountainous areas with an increase in population density. Cultivation of mountain slopes meant increasing erosion and the transport of the solid matter by rivers. Additionally, there was an increased need of wood as a raw material for energy production and building. As a result, an ever-increasing quantity of floodwater, rich in sand and silt deposits, was transported to the low-lying plains of the Emilia-Romagna region and Venetia. Contemporaneously, the inhabitants of the plain tried harder than ever to obtain additional cultivable land by irrigating the gravelly heathlands in the Alpine foothills, using transported solid material for filling in sunken areas of agricultural land and draining works with the embankment of all flood-producing watercourses at higher levels by channelling them to hydrometric levels lower than those of the low-lying basins they passed through. By this means tens of thousands of hectares of land were drained in the period 1540-1620 (Rigobello, 1976; Cazzola, 1978). Cazzola (1987) denoted the second half of the sixteenth century as "the age of reclamation and redemption".

At the end of the sixteenth century the entire hydraulic system in the lower reaches of the Po was very disturbed or at least structurally altered to such an extent that, as contemporaries put it, the water did not know which way to turn. It apparently flowed in various directions, depending on the level of the Po Grande, i.e., the new branch of the river which had been created by breaching the banks at Ficarolo (in the Province of Rovigo) in 1152. These factors conditioned the general tendency of the Po delta to migrate northwards as well as the tendency of some of its right-bank tributaries to migrate from east to west.

Furthermore, population pressure in conjunction with deforestation and the cultivation of mountain slopes helped to aggravate the effects of flooding. Increased erosion on slopes and transport of material led to a raising of river bed levels and a greater risk of flooding. On the other hand, reclamation involved a massive reduction of areas occupied by marshes or floodwater. It produced a considerable increase in the amount of water channelled off from reclaimed land and reduced the extent of the natural area usually inundated by floods. The above facts complicate an objective assessment of extremity of floods.

Gerlach (1990) studied the changes of the system on the River Main and showed that the medieval river was a broad meandering stream with natural bluffs and gravel-covered slip-off slopes which could change their position from year to 
year. Complaints about the silting, or rather sanding, up of the river became more frequent in the fifteenth century and again at the beginning of the nineteenth century. Ever since the late Middle Ages embankment protection with piles, fascines, caissons and dams was quite common. Bridges, mills and weirs also have to be mentioned amongst the direct interventions, as they modified the river flow and thus also sedimentation. In spite of these numerous structures it has to be assumed that there was no fundamental change of the river. The Main largely continued to develop as a natural meandering system with frequent relocations and branchings. Most of the historic meanders would widen their loops, migrate downstream and eventually be cut through at their necks. People reacted to these changes, but did not change the system. There are many written sources in support of this statement. It is interesting to note that there were several phases in the sixteenth century when natural changes and construction work reacting to them became more frequent. This is true for the 1540 s, for the years between 1565 and 1575 , and again for the 1590 s. There are only a few changes where a human cause can be assumed, as when the construction of weirs or diversion channels caused erosion elsewhere or when embankments were damaged by rafting.

Changes in the bed of the Vltava at Prague according to the results of investigation by Hrdlička (1994) are described in detail by Kotyza et al. (1995). Many water weirs were built for the needs of water mills. The declivity of the river and its carrying force were lowered by a damming of the water flow. This caused sedimentation of sand and gravel material and consequently an increase of some 3 $3.5 \mathrm{~m}$ in the bottom of the river bed and in the river level. Furthermore, both sides of the river at Prague were artificially altered by different material being dropped directly on the river bed. The result was a shortening of the transverse river profile at any one place of up to $40 \mathrm{~m}$. No doubt these artificial impacts also influenced flood activity, mainly from the sixteenth century.

Another example of human influence on the run-off process is connected with the pond economy in the Czech Lands during the sixteenth century when many ponds were established in order to bring economic profit to the owners. They usually took water from any river as, for example, was the case on the Morava near Olomouc (Hurt, 1960). Many water weirs on the river were built for this purpose, something which caused problems at the time of floods. Because of the many weirs the water of the Morava could not spread freely in the usually flooded forest areas but was driven by back pressure, thus flooding upper-lying fields formerly protected from floods. The weirs divided the Morava river into sections between which the water flowed very slowly or was completely stopped. Another consequence of the building of the weirs was a change of the old river bed to a new one or new river branches. For contemporaries, these facts changed not only the conditions of the water run-off, but also their perception of floods. 


\subsection{SYNTHESIS OF FLOODS OF THE SELECTED EUROPEAN RIVERS}

Ideally, the deduction of trends from documentary flood information requires complete records. In the absence of continuous observations it cannot be excluded, of course, that the discovery of additional evidence might increase the number of known events or shed new light on existing evidence. However, if substantial evidence is available for major tributaries in the catchment area such data can be used to cross-check the consistency and reliability of the main series, as severe floods are known to always occur over a wide area.

Taking due regard of the above facts, the presented results are of great value. From former analyses of rivers in Germany and the Czech Lands, it is clear that a more or less continual increase in the number of floods during the sixteenth century can be observed. It can be suggested that on a smaller scale a rise of flood frequency is connected with an increase in the record density during this century (e.g., in the Czech Lands). But more probably an increase of flood activity was caused by important changes in climatic patterns. As can be seen from the precipitation indices for the two countries (Glaser et al., this volume) there is a prevalence of wetter seasons (e.g., winter, summer) in the second half of the sixteenth century in comparison with the first half.

The analysis shows that a flood is really a local or regional phenomenon depending on the scale of the forcing synoptic patterns. Only in certain cases is there a coincidence in the occurrence of severe floods over a broader region, as, for example, with the intensive continuous rains in August 1501 in. Germany and Bohemia, and in July 1584 on the Rhine at Basel and on rivers in Germany, or from the melting snow and ice drift in March 1595 in Germany and Bohemia. Moreover, differences in the causes of floods are conditioned regionally, i.e., by different climatic and geographical patterns. This is shown very well by the comparison of central European and Mediterranean areas. In the former region, floods originating from the melting of snow or ice drift are very frequent, while in the latter area floods caused by rains clearly prevail. This is the reason for the prevalence of winter and early spring floods in central Europe and autumn floods in the Mediterranean (with the exception of Andalusia which has a high share of winter floods caused by rains - see Table III).

Figure 19 shows the relative decennial occurrence of severe and extreme floods during the sixteenth century in the regions studied. They occurred most frequently during the 1560s in the central European region; in the 1550s in Germany; and in the $1570 \mathrm{~s}$ and the $1590 \mathrm{~s}$ in Bohemia. A lower number of severe floods was recorded in central Europe mainly in the second, third and fifth decades of the sixteenth century. This is in good agrement with the general evolution of seasonal precipitation patterns during the sixteenth century in central Europe (see Glaser et al., this volume). On the other hand, flood patterns were more complex in the Mediterranean area. In northern Italy, for instance, extreme floods were distributed 
Rhine (Basle)
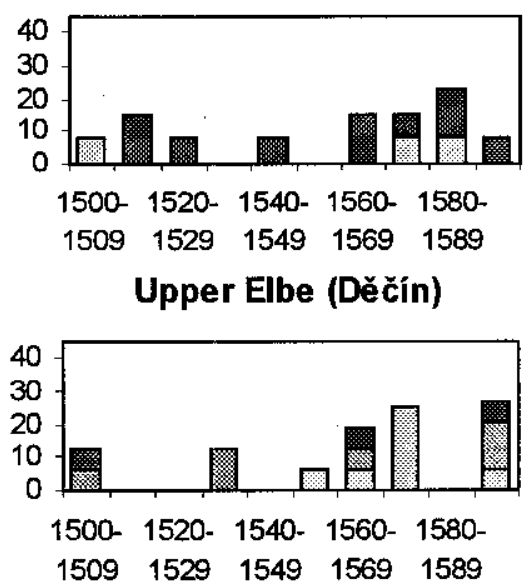

North and Central Italy
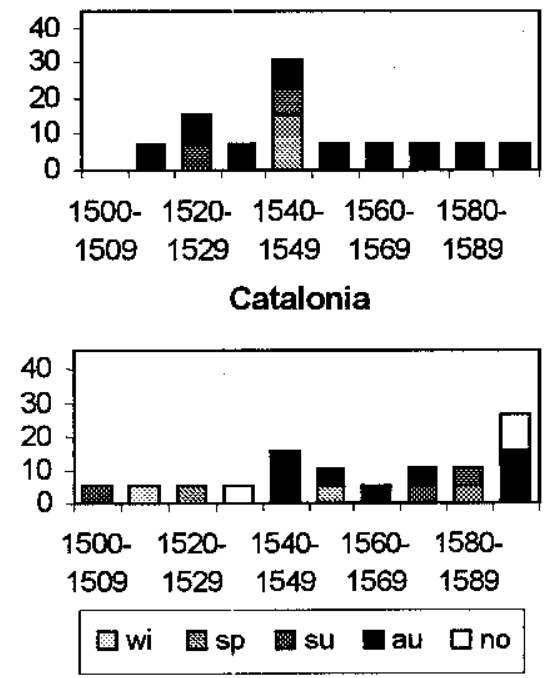

Main, Saale, Middle Elbe
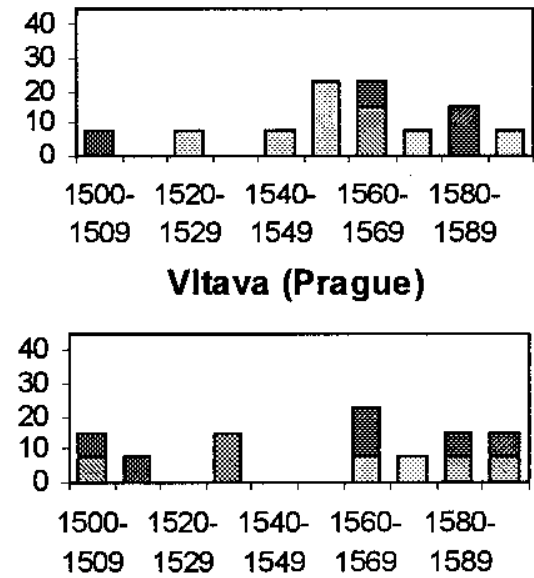

Garonne (Toulouse)
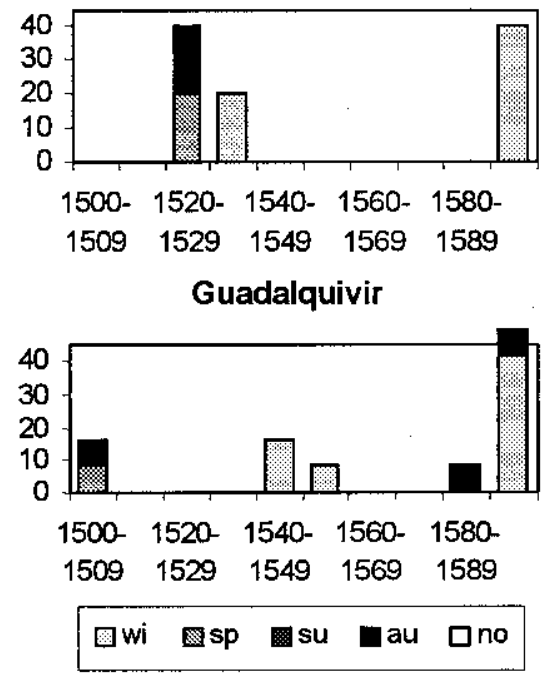

Figure 19. Decennial frequencies (\%) and seasonality of severe and extreme floods in selected regions of central and southern Europe during the sixteenth century. Explanation: wi - winter, $\mathrm{sp}$ - spring, su - summer, au - autumn, no - without date.

more or less regularly with the highest frequency in the $1510 \mathrm{~s}-1540$ s and in the $1590 \mathrm{~s}$. On the Iberian Peninsula the maximum appeared in the $1540 \mathrm{~s}$ and $1590 \mathrm{~s}$ (for the Guadalquivir River, half of all the severe floods occurred in the 1590s). The second maximum is in good agreement with wetter patterns during the last decade of the sixteenth century according to the precipitation indices for Spain (Glaser et al., this volume). In spite of the small number of severe floods on the Garonne, there is also a maximum in the 1590 s, as well as in the 1520 s. 
As can be seen from Table III, the upper Garonne (Toulouse), all Italian rivers and the Segre in Spain had a greater share of floods in the first half of the sixteenth century (from $55 \%$ for the Tanaro to $75 \%$ for the Panaro). The Ebro and Ter showed the same number of floods in both parts of the century. On the other hand, all other investigated rivers had a prevalence of floods in the second half of the century (from $53 \%$ for the Vltava to $78 \%$ for the Main). Fluctuations in the seasonality of floods are influenced in some cases by the very low number of recorded floods during the century (e.g. the Ebro) or by a higher number of floods without exact seasonal specification (e.g. the middle Garonne at Agen or the Segre). Possible large changes in the character of seasonality in one catchment area are not usually confirmed by another one. The situation on the Elbe is a good example. It appears that in comparison with the first half of the sixteenth century there was a relative increase in the number of winter floods and a decrease in the number of spring floods on the middle Elbe in the second half of the century. However, the tendency for the upper Elbe and the Saale is totally opposite. As a result of this large seasonal inconsistency between different catchments, formulation of any conclusions concerning possible seasonal changes between the two halves of the sixteenth century would be more or less speculative.

\section{Conclusion}

Results of an analysis of sixteenth-century floods on selected European rivers are partly biased by a different methodological approach for the delimitation of extreme floods. Furthermore, incomplete documentary evidence about floods can partly diminish the validity of presented results. Nevertheless, the analysis shows existing possibilities for the reconstruction of flood events prior to the period of instrumental measurements. Despite existing limitations, historical and epigraphical records can produce high resolution data about floods for the preinstrumental period. On the other hand, certain limitations of this information should be taken in consideration when using it for implications of flood activity in the instrumental period, namely major anthropogenic impacts in the catchments of selected rivers significantly changed the run-off process in comparison with the situation presented in this study. 
Table III

Relative seasonal frequencies of floods in central and southern European rivers in the first and second halves of the sixteenth century ( $\mathrm{N}$ - number of floods, $\mathrm{P}$ - shares of 50-year period on the entire number of floods in the sixteenth century in \%)

\begin{tabular}{|c|c|c|c|c|c|c|c|c|}
\hline River - place & Period & $\mathrm{N}$ & $\mathrm{P}$ & Winter & Spring & Summer & Autumn & Unknown \\
\hline \multirow[t]{2}{*}{ Rhine - Basel } & $1500-1549$ & 5 & 38.5 & 20.0 & - & 80.0 & - & - \\
\hline & $1550-1599$ & 8 & 61.5 & 25.0 & - & 75.0 & - & - \\
\hline \multirow[t]{2}{*}{ Main } & $1500-1549$ & 11 & 22.4 & 54.5 & 18.2 & 9.1 & - & 18.2 \\
\hline & $1550-1599$ & 38 & 77.6 & 57.9 & 10.5 & 13.2 & 5.3 & 13.2 \\
\hline \multirow[t]{2}{*}{ Pegnitz } & $1500-1549$ & 12 & 26.7 & 33.3 & 16.7 & 16.7 & - & 33.3 \\
\hline & $1550-1599$ & 33 & 73.3 & 51.5 & 21.2 & 21.2 & 6.1 & - \\
\hline \multirow[t]{2}{*}{ Middle Elbe } & $1500-1549$ & 24 & 42.9 & 16.7 & 41.7 & 25.0 & 8.3 & 8.3 \\
\hline & $1550-1599$ & 32 & 57.1 & 59.4 & 9.4 & 28.1 & - & 3.1 \\
\hline \multirow[t]{2}{*}{ Saale } & $1500-1549$ & 11 & 44.0 & 54.5 & 9.1 & 9.1 & 18.2 & 9.1 \\
\hline & $1550-1599$ & 14 & 56.0 & 28.6 & 21.4 & 35.7 & - & 14.3 \\
\hline \multirow{2}{*}{$\begin{array}{l}\text { Upper Elbe } \\
\text { (Labe) - Děčín }\end{array}$} & $1500-1549$ & 16 & 24.2 & 37.5 & 18.8 & 18.8 & 18.8 & 6.1 \\
\hline & $1550-1599$ & 50 & 75.8 & 32.0 & 28.0 & 38.0 & 2.0 & - \\
\hline \multirow{2}{*}{$\begin{array}{l}\text { Vltava - } \\
\text { Prague }\end{array}$} & $1500-1549$ & 22 & 46.8 & 9.1 & 22.7 & 63.6 & 4.5 & - \\
\hline & $1550-1599$ & 25 & 53.2 & 12.0 & 32.0 & 48.0 & 8.0 & - \\
\hline \multirow[t]{2}{*}{ Po } & $1500-1549$ & 19 & 61.3 & 10.5 & 26.3 & 5.3 & 57.9 & - \\
\hline & $1550-1599$ & 12 & 38.7 & - & 33.3 & 16.7 & 50.0 & - \\
\hline \multirow[t]{2}{*}{ Bormida } & $1500-1549$ & 5 & 62.5 & - & 40.0 & 20.0 & 40.0 & - \\
\hline & $1550-1599$ & 3 & 37.5 & - & - & - & 100.0 & \\
\hline \multirow[t]{2}{*}{ Panaro } & $1500-1549$ & 6 & 75.0 & 16.7 & - & 33.3 & 50.0 & - \\
\hline & $1550-1599$ & 2 & 25.0 & - & - & 50.0 & 50.0 & - \\
\hline \multirow[t]{2}{*}{ Secchia } & $1500-1549$ & 15 & 68.2 & 20.0 & 40.0 & 6.7 & 20.0 & 13.3 \\
\hline & $1550-1599$ & 7 & 31.8 & 28.6 & 14.3 & 14.3 & 42.8 & - \\
\hline \multirow[t]{2}{*}{ Tanaro } & $1500-1549$ & 6 & 54.5 & - & 50.0 & 16.7 & 33.3 & - \\
\hline & $1550-1599$ & 5 & 45.5 & 20.0 & - & 20.0 & 60.0 & - \\
\hline \multirow[t]{2}{*}{ Adige } & $1500-1549$ & 11 & 68.8 & - & 27.3 & 9.1 & 45.4 & 18.2 \\
\hline & $1550-1599$ & 5 & 31.2 & - & - & 40.0 & 40.0 & 20.0 \\
\hline \multirow[t]{2}{*}{ Arno } & $1500-1549$ & 7 & 63.6 & 14.3 & - & 42.9 & 42.9 & - \\
\hline & $1550-1599$ & 4 & 36.4 & - & - & - & 100.0 & - \\
\hline \multirow[t]{2}{*}{ Tiber } & $1500-1549$ & 4 & 57.1 & - & - & - & 100.0 & - \\
\hline & $1550-1599$ & 3 & 42.9 & 33.3 & - & - & 66.7 & - \\
\hline \multirow{2}{*}{$\begin{array}{l}\text { Garonne - } \\
\text { Toulouse }\end{array}$} & $1500-1549$ & 7 & 70.0 & 14.2 & 28.6 & - & 28.6 & 28.6 \\
\hline & $1550-1599$ & 3 & 30.0 & 66.7 & 33.3 & - & - & - \\
\hline \multirow{2}{*}{$\begin{array}{l}\text { Garonne - } \\
\text { Agen }\end{array}$} & $1500-1549$ & 5 & 31.2 & - & - & 20.0 & 60.0 & 20.0 \\
\hline & $1550-1599$ & 11 & 68.8 & 27.3 & 9.1 & 9.1 & 9.1 & 45.4 \\
\hline \multirow[t]{2}{*}{ Ebro - Tortosa } & $1500-1549$ & 1 & 50.0 & - & - & - & 100.0 & - \\
\hline & $1550-1599$ & 1 & 50.0 & - & 100.0 & - & - & - \\
\hline
\end{tabular}


RUDOLF BRÁZDIL ET AL.

Table III

(Continued)

\begin{tabular}{lcccccccc}
\hline River - place & Period & $\mathrm{N}$ & $\mathrm{P}$ & Winter & Spring & Summer & Autumn & Unknown \\
\hline Segre - Lerida & $1500-1549$ & 5 & 62.5 & - & 40.0 & - & 20.0 & 40.0 \\
& $1550-1599$ & 3 & 37.5 & - & 33.3 & & & 66.7 \\
Ter - Gerona & $1500-1549$ & 5 & 50.0 & 40.0 & - & - & 60.0 & - \\
& $1550-1599$ & 5 & 50.0 & 20.0 & & & 80.0 & \\
Uadis - & $1500-1549$ & 3 & 42.9 & - & 33.3 & 33.3 & 33.3 & - \\
Barcelona & $1550-1599$ & 4 & 57.1 & - & - & 50.0 & 50.0 & - \\
Guadalquivir - & $1500-1549$ & 4 & 33.3 & 50.0 & 25.0 & - & 25.0 & - \\
Sevilla & $1550-1599$ & 8 & 66.7 & 75.0 & - & - & 25.0 & - \\
Guadalmedina & $1500-1549$ & 2 & 28.6 & 50.0 & - & - & 50.0 & - \\
- Malaga & $1550-1599$ & 5 & 71.4 & 40.0 & - & - & 60.0 & - \\
\hline
\end{tabular}

\section{Acknowledgements}

We thank John Kington, Climatic Research Unit, University of East Anglia, Norwich and Paul-Anthon Nielson, Institute of History, University of Bern for kindly correcting the English version of this paper. Sincere thanks particularly belong to G. R. Demarée, Royal Meteorological Institute, Brussels for his valuable comments and complements in the text, as well as to the two other reviewers, $\mathbf{H}$. Mendel, Bundesanstalt für Gewässerkunde, Koblenz and K.-H. Pörtge, Institute of Geography, University of Erfurt. We also thank K. Wepler, Institute of Geography, University of Würzburg for kindly preparation of Figures 5-9. The research for this paper was supported by following agencies:

Czech Republic: Grant No. 205/95/0506 of the Grant Agency of the Czech Republic

Germany: DFG, Project No. Ja 625/1-2 (1992-1996) and the BMBF project "Terrestrische Paläoklimatologie" (1995-1997)

Italy: CNR: Programme Environment and Climate of the European Commission, contracts ENV4.-CT95-0092 and PL 970288, partially also PRISMA 2 Project (MURST)

Spain: A post-doctoral grant (FPU, MEC, 1995-1996), contract 94.428/1 (INM) and the project CLI95-1928-C02-02 (CICYT).

Switzerland: the Swiss National Science Foundation, Priority Programme Environment, No. 5001, 34888 and project 11-52786.97 (FLOODRISK). 


\section{References}

Alvarez Vazquez, J. A.: 1986, 'Drought and rainy periods in the province of Zamora in the 17th, 18th and 19th centuries', in Lopez Vera, F. (ed.), Quaternary Climate in Western Mediterranean, Universidad Autonoma, Madrid, pp. 221-235.

Antoine, J.-M., Desailly, B., and Métailié, J.-P.: 1991, 'La chronologie des crues et des phénomènes torrentiels dans les Pyrénées (XVIIle-XXe siècle). Premiers résultats et problèmes d'interprétation', in Métailié, J.-P. (ed.), Risques et aménagement dans les Pyrénées, GDR Isard, Toulouse, pp. 31-58.

BA Wasserwirtschaft (ed.): 1991, Ursachenanalyse der Hochwasser 1987 - Ergebnisse der Untersuchungen, Mitteilungen des Bundesamtes für Wasserwirtschaft 4, Bern, 85 pp.

Babió Wall, M.: 1990, Aproximación Etnográfica del Puerto y Río de Sevilla en el Siglo XVI, Editorial Don Quijote, Sevilla, $254 \mathrm{pp}$.

Barriendos, M.: 1994, El clima histórico de Catalunya. Aproximación a sus caracteristicas generales (ss. $X V-X I X)$, Department of Physical Geography, University of Barcelona, manuscript.

Barriendos, M: 1995a, 'La climatologia histórica en el estudio de los riesgos climáticos. El episodio de noviembre de 1617 en Catalunya', in Creus, J. (ed.), Situaciones de riesgo climático en España, Instituto Pirenaico de Ecología, Jaca, pp. 73-83.

Barriendos, M.: 1995b, 'Oscilaciones climáticas seculares a través de las inundaciones catastróficas en el litoral mediterráneo: siglos XIV-XIX’, Estudios Geográficos 56, 223-237.

Barriendos, M. and Martín-Vide, J.: 1998, 'Secular climatic oscillations as indicated by catastrophic floods in the Spanish Mediterranean coastal area (14th-19th centuries)', Climatic Change 38, 473-491.

Bayerisches Staatsministerium für Landesentwicklung und Umweltfragen: 1985, Wasserwirtschaftliche Rahmenuntersuchung Donau und Main, München, 204 pp.

Bell, W. T. and Ogilvie, A. E. J.: 1978, 'Weather compilation as a source of data for the reconstruction of European climate during the medieval period', Climatic Change 1, 331-348.

Bork, H. R.: 1988, Bodenerosion und Umwelt. Verlauf, Ursachen und Folgen der Mittelalterlichen und neuzeitlichen Bodenerosion, Bodenprozesse, Modelle und Simulationen, Landschaftsgent:se und Landschaftsökologie, Technische Universität Braunschweig, H. 13, $249 \mathrm{pp}$.

Brádka, J.: 1967, ‘Meteorologické př́činy povodní ve Slezsku’, Meteorol. Zpr. 20, 3-9.

Camuffo, D. and Etzi, S.: 1995, 'Climatic features during the Spörer and Maunder minima', in Frenzel, B. (ed.), Solar Output and Climate during the Holocene, Paleoclimate Research 16, Fischer Verlag, Stuttgart, New York, pp. 105-125.

Camuffo, D. and Enzi, S.: 1996, 'The analysis of two bi-millenary series: Tiber and Po river floods', in Jones, P. D., Bradley, R. S. and Jouzel, J. (eds.), Climatic Variations and Forcing Mechanisms of the last 2000 years, NATO ASI Series, Vol. 41, Springer Verlag, Berlin, Heidelberg, pp. $433-450$.

Casale, R., Havno, K. and Samuels, P. (eds.): 1997, Ribamod. River Basin Modelling, Management and Flood Mitigation. Concerted Action, Proceedings of the first expert meeting, Copenhagen, 10 and 11 October 1996, European Commission, Hydrological and Hydrogeological Risks, Luxembourg, $167 \mathrm{pp}$.

Casale, R., Pedroli, G. B. and Samuels, P. (eds.): 1998, Ribamod. River Basin Modelling, Management and Flood Mitigation. Concerted Action, Proceedings of the first workshop, 
Delft, 13 to 15 February 1997, European Commission, Hydrological and Hydrogeological Risks, Luxembourg, 389 pp.

Castillo Requena, J. M.: 1989, El Clima de Andalucía, Instituto de Estudios Almerienses, Universidad de Granada, Granada, 549 pp.

Cazzola, F.: 1978, 'Bonifiche e investimenti fondiari', Storia dell'Emilia Romagna II, 209-228.

Cazzola, F.: 1987, 'La bonifica del Polesine di Ferrra dall'etr estense al 1885', La grande bonificazione ferrarese $\mathbf{I}$, Ferrara.

Chalande, J.: 1912, 'Les inondations et les formations alluviales dans le bassin de la Garonne à Toulouse depuis le XIle siècle', Mémoires de l'Académie des Sciences, Inscriptions et Belles Lettres de Toulouse, 12, 7-16.

Champion, M.: 1862, Les inondations en France depuis le Vle siècle jusqu'à nos jours, Dunod, Paris, 6 Vol.

Colosía Rodríguez, M. I. P.: 1978, 'La Crisis de Málaga en 1661 Según los Fondos Documentales de la Biblioteca Nacional', Baetica 1, 337-357.

Deutsch, M.: 1993, 'Hochwassermarken an der Neumühle von Halle', Sachsen-Anhalt-Journal 3, 20-21.

Deutsch, M. and Pörtge, K.-H.: 1996, 'Aussergewöhnliche Niederschläge und Hochwässer in Thüringen am Beispiel des Hochwassers der Unstrut vom Juli 1926 im Altkreis Mühlhausen', in Mäusbacher, R. and Schulte, A. (eds.), Beiträge zur Physiogeographie, Heidelberger Geographische Arbeiten 104, 289-299.

Engel, H.: 1995, 'Hochwasser am Rhein, Ursachen und Entwicklungen - Möglichkeiten und Grenzen vor Vorhersagen', in Hochwasserkatastrophen - Ursachen und Präventivmassnahmen, Unterlagen zur Konferenz am 29. und 30. Juni 1995 in Köln.

Fink, A., Ulbrich, U. and Engel, H.: 1996, 'Aspects of the January 1995 flood in Germany', Weather 51, 34-39.

Font Tullot, I.: 1988, Historia del Clima en España. Cambios Climáticos y sus Causas, Instituto Nacional de Meteorología, Madrid, 297 pp.

Frances, F., Salas, J. D. and Boes, D. C.: 1994, 'Flood frequency analysis with systematic and historical or paleoflood data based on the two-parameter general extreme value models', Water Resources Research 30, 1653-1664.

Fritz, S.: s.d., Cosmographia. Fortsetzung der Erfurtischen Chroniken von Samuel Fritz, Stadtarchiv Erfurt, sign. 5/100/42, p. 152.

Galabert, F.: 1918, Dépouillement des archives de la ville de Toulouse à propos des inondations de la Garonne, Handwritten notes, Toulouse City Archives (B88).

Gasser, O.: 1957, 'Die Wasserspiegelschwankungen des Bodensees und ihre meteorologischen Grundlagen', Ber. Dtsch. Wetterd. 35, 1-24.

Gazelle, F.: 1989, 'Le rôle des Pyrénées dans l'abondance de la Garonne toulousaine', Revue Géographique des Pyrénées et du Sud-Ouest 60, 503-520.

Gees, A.: 1997, Analyse historischer und seltener Hochwasser in der Schweiz. Bedeutung für das Bemessungshochwasser, Geographica Bernensia G53, 156 pp.

Gellens, D. and Schädler, B.: 1996, Assessment of the water balance of the Broye, the Ergolz and the Murg catchments in the present climate conditions and in $2 \mathrm{xCO}_{2}$ climate scenarios adopted by the International Commission for the Hydrology of the River Rhine (CHR), Final Report, Royal Meteorological Institute of Belgium, Brussels, 42 pp.

Gellens, D. and Schädler, B.: 1997, 'Comparaison des réponses du bilan hydrique de bassins situés en Belgique et en Suisse à un changement de climat', Rev. Sci. Eau 3, 395-414. 
Gerlach, R.: 1990, Flussdynamik des Mains unter dem Einfluss des Menschen seit dem Spätmittelalter, Forschungen zur deutschen Landeskunde, Bd. 234, 247 pp.

Glaser, R., Brázdil, R., Pfister, C., Dobrovolný, P., Barriendos, M., Bokwa, A., Camuffo, D., Kotyza, O., Limanowka, D., Racz, L. and Rodrigo, F.S.: 1998, 'Seasonal temperature and precipitation fluctuations in selected parts of Europe during the sixteenth century', Climatic Change, this volume.

Glaser, R. and Hagedorn, H.: 1990, 'Die Ueberschwemmungskatastrophe von 1784 im Maintal', Die Erde 121, 1-14.

Götzinger, E. (ed.): 1879, 'Watt (Vadian) Joachim [1484-1551] Diarium 1516-1533', Deutsche Historische Schriften 3, 227-528.

Grabs, W. (ed.): 1997, Impact of Climate Change on Hydrological Regimes and Water Resources Management in the Rhine Basin, CHR-Report No. I-16, Lelystad.

Guidoboni, E.: 1998, 'Human factors, extreme events and floods in the Lower Po Plain (Northern Italy) in the 16th century', Environment and History 4, 279-308.

Harington, C. R.: 1992, The year without a summer? World climate in 1816, Canadian Museum of Nature, Ottawa, $335 \mathrm{pp}$.

Hladný, J. et al.: 1996, Dopady možné zmèny klimatu na hydrologii a vodní zdroje v České republice, Národni klimatický program ČR 20, Praha, 138 pp.

Houghton, J. T., Meira Filho, L. G., Callander, B. A., Harris, N., Kattenberg, A., and Maskell, K. (eds.): 1996, Climate Change 1995. The Science of Climate Change, University Press, Cambridge, $572 \mathrm{pp}$.

Hrdlička, L.: 1994, 'The archeological study of the historical centre of Prague: 1969-1993', in 25 Years of Archaeological Research in Bohemia, Památky archeologické - Supplementum 1, pp. 174-184.

Hurt, R.: 1960, Dëjiny rybnikářství na Moravě a ve Slezsku, I. díl, Manuscript, 274 pp.

Kabubi, J. N., Gellens, D. and Demarée, G. R.: 1995, 'Response of an upland equatorial African basin to a $\mathrm{CO}_{2}$-induced climatic change', Hydrological Sciences - Journal - des Sciences Hydrologiques 40, 453-470.

Kakos, V.: 1983, 'Hydrometeorologický rozbor povodní na Vltavě v Praze za období 1873 až 1982', Meteorol Zpr. 36, 171-181.

Kakos, V.: 1985, 'Hydrometeorologická analýza povodňových situací v povodi Labe', Meteorol. Zpr. 38, 148-151.

Kakos, V.: 1990, 'Fluctuations in the frequency of floods on the Vltava River in Prague in relation to meteorological observations at Prague-Klementinum', in Brázdil, R. (ed.), Climatic Change in the Historical and the Instrumental Periods, Masaryk University, Brno, pp. 319-322.

Kakos, V.: 1997, 'Extrémní srážky a povodně v červenci 1997', Vodni cesty a plavba 4, 10-18.

Kašpárek, L., Bušek, M.: 1990, 'Vliv vltavské kaskády na povodňový režim Vltavy v Praze', Vodni hospodár̆ství 7, 280-286.

Keller, R. (ed.): 1979, Hydrologischer Atlas der Bundesrepublik Deutschland - Textband, Harald Boldt Verlag, Boppard, 365 pp.

Kobelt, K.: 1926, Die Regulierung des Bodensees. Hochwasserschutz, Kraftnutzung und Schiffahrt, Schriften des Eidg. Amtes f. Wasserwirtschaft, Bern, 125 pp.

Kotyza, O., Cvrk, F. and Pažourek, V.: 1995, Historické povodně na dolnim Labi a Vltavě, Okresní muzeum v Děčíně, Děčín, 169 pp.

Krahe, P.: 1997, 'Hochwasser und Klimafluktuationen am Rhein seit dem Mittelalter', in Immendorf, R. (ed.), Hochwasser. Natur im Überfluss?, C. F. Müller, Heidelberg, pp. 57-82. 
Kuusisto, E., Lemmelä, R., Liebscher, H. and Nobilis, F.: 1994, Climate and Water in Europe, Some Recent Issues, World Meteorological Organization, Technical Report of Rapporteurs Working Group on Hydrology, Helsinki, 36 pp.

Kwadijk, J.: 1993, The impact of climatic change on the discharge of the River Rhine, Ph.D. Thesis, University of Utrecht, $256 \mathrm{pp}$.

Lafaille, G. de: 1682-1701, Annales de la Ville de Toulouse, Coulomyes, Toulouse, 2 Vol.

Marsan, F.: 1893, 'Météorologie ancienne du midi pyrénéen', Revue des Pyrénées 5, 540-555.

Mateu, A.: 1982, 'Agen, ville médiane exemplaire', in Ferro, M. (ed.), Une histoire de la Garonne, Ramsay, Paris, pp. 408-432.

Mendel, H. G., Fischer, P. and Hermann, A.: 1997, Hochwasser Gedanken über Ursachen und Vorsorge aus hydrologischer Sicht, Bundesanstalt für Gewässerkunde, BfG-1022, Koblenz, 53 pp.

Pardé, M.: 1935, 'Le régime de la Garonne', Revue Géographique des Pyrénées et du Sud-Ouest 6, 105-261.

Pavese, M. P., Banzon, V., Colacino, M., Gregori, G. P. and Pasqua, M.: 1992, 'Three historical data series on floods and anomalous climatic events in Italy', in Bradley, R. S. and Jones, P. D. (eds.), Climate Since A.D. 1500, Routledge, London and New York, pp. 155-170.

Pfister, C.: 1985, 'Snow cover, snow-lines and glaciers in Central Europe since the 16th century', in Tooley, M. J. (ed.), The Climatic Scene, George Allen and Unwin, London, pp. 154-173.

Pfister, C.: 1988, Klimageschichte der Schweiz 1525-1860, Das Klima der Schweiz von 1525-1860 und seine Bedeutung in der Geschichte von Bevölkerung und Landwirtschaft, Paul Haupt, Bern and Stuttgart, $184 \mathrm{pp}$. and supplement.

Pfister, C.: 1992, 'Monthly temperature and precipitation in central Europe 1525-1979: quantifying documentary evidence on weather and its effects', in Bradley, R. S. and Jones, P. D. (eds.), Climate Since A.D. 1500, Routledge, London and New York, pp. 118-142.

Pfister, C.: 1996, 'Häufig, selten oder nie. Zur Wiederkehrperiode der grossräumigen Überschwemmungen im Schweizer Alpenraum seit 1500', in Hurni, H., Kienholz, H., Wanner, H. and Wiesmann, U. (eds.), Umwelt, Mensch, Gebirge. Beiträge zur Dynamik von Natur- und Lebensraum, Jahrbuch der Geographischen Gesellschaft Bern, Bd. 59/1994-1996, Bern, pp. 139-148.

Pfister, C.: 1999, Wetternachhersage. 500 Jahre Klimavariationen und Naturkatastrophen (14961995), Paul Haupt, Berm, Stuttgart, Wien, 304 pp.

Pfister, C. and Brázdil, R.: 1999, 'Climatic variability in sixteenth-century Europe and its social dimension: A synthesis', Climatic Change, this volume.

Pfister, C., Brázdil, R., Glaser, R., Barriendos, M., Camuffo, D., Deutsch, M., Dobrovolný, P., Enzi, S., Guidoboni, E., Kotyza, O., Militzer, S., Rácz, L., Rodrigo, F. S.: 1999, 'Documentary evidence on climate in sixteenth-century Europe', Climatic Change, this volume.

Pfister, C. and Hächler, S.: 1991, 'Ueberschwemmungskatastrophen im Schweizer Alpenraum seit dem Spätmittelalter - Raumzeitliche Rekonstruktion von Schadensmustern auf der Basis historischer Quellen', in Glaser, R. and Walsh, R. (eds.), Historical Climatology in Different Climatic Zones, Würzb. Geograph. Arbeiten 80, pp. 127-148.

Pötzsch, C. G.: 1784, Chronologische Geschichte der grossen Wasserfluthen des Elbstroms, Walther, Dresden, $232 \mathrm{pp}$.

Přenosilová, E.: 1994, Dủsledky klimatických zmèn na hospodařeni s vodou v nádržich, Národní klimatický program ČR 16, Praha, $97 \mathrm{pp}$.

Rigobello, B.: 1976, 'Le bonifiche estensi in Polesine dopo le rotte di Malopera e di Castagnaro, Lendinara'. 
Röthlisberger, G.: 1991, Chronik der Unwetterschäden in der Schweiz, Ber. Eidgenöss. Forsch. anst. Wald, Schnee und Landsch., 330, Birmensdorf, 122 pp.

SMEPAG: 1989, Monographie des crues de la Garonne (du pont du Roy au Bec d'Ambès), Syndicat Mixte d'Etude et de Programmation pour l'Aménagement de la Garonne, Toulouse, Bordeaux, 2 tomes.

Serret, J.: 1900, Les débordements de la Garonne et ses affluents depuis les temps anciens jusqu'à nos jours, Imprimerie et Lithographie Agenaises, Agen, 98 pp.

Soukalová, E., Řehánek, T. and Šiftař, Z.: 1997, 'Odtoková situace za povodně v červenci 1997 v povodích Odry, Moravy a Labe', Meteorol. Zpr. 50, 183-190.

Spanknebel, H. G., Kaufmann, M. and Pörtge, K.-H.: 1994, 'Das Aprilhochwasser in Thüringen', Deutsche Gewässerkundliche Mitteilungen 6, 191-195.

Vigneau, J.-P.: 1986, Climats et climat des Pyrénées-Orientales, Toulouse, J.-P. Vigneau éd., thèse de géographie, Université de Toulouse-Le Mirail, Toulouse, $618 \mathrm{pp}$.

Walawender, A.: 1932, Kronika klesk elementarnych $w$ Polsce $i$ w krajach sasiednich $w$ latach 1450-1586. Badania z Dziejów Spolecznych i Gospodarczych, Lwów, 112 and 299 pp.

Weikinn, C.: 1960, Quellentexte zur Witterungsgeschichte Europas von der Zeitwende bis zum Jahre 1850 (Hydrographie), Teil 2 (1501-1600), Akademie Verlag, Berlin, 447 pp.

Witte, W.: 1991, 'Der Aussagewert von historischen hydrologischen Daten im Vergleich zu meteorologischen und (para-)phänologischen Daten für die Rekonstruktion der Witterung im Mittelrheingebiet seit dem 14. Jahrhundert', in Glaser, R. and Walsh, R. (eds.), Historical Climatology in Different Climatic Zones, Würzb. Geograph. Arbeiten 80, pp. 149-181.

(Received 29 October 1997; in revised form 26 April 1999) 